by

G. T. Jannik

Westinghouse Savannah River Company

Savannah River Site

Aiken, South Carolina 29808

B. Biunt

This paper was prepared in connection with work done under the above contract number with the U.S. Department of Energy. By acceptance of this paper, the publisher and/or recipient acknowledges the U.S. Government's right to retain a nonexclusive, royalty-free license in and to any copyright covering this paper, along with the right to reproduce and to authorize others to reproduce all or part of the copyrighted paper. 


\section{DISCLAIMER}

This report was prepared as an account of work sponsored by an agency of the United States Government. Neither the United States Government nor any agency thereof, nor any of their employees, makes any warranty, express or implied, or assumes any legal liability or responsibility for the accuracy, completeness, or usefulness of any information, apparatus, product, or process disclosed, or represents that its use would not infringe privately owned rights. Reference herein to any specific commercial product, process, or service by trade name, trademark, manufacturer, or otherwise does not necessarily constitute or imply its endorsement, recommendation, or favoring by the United States Government or any agency thereof. The views and opinions of authors expressed herein do not necessarily state or reflect those of the United States Government or any agency thereof.

This report has been reproduced directly from the best available copy.

Available to DOE and DOE contractors from the Office of Scientific and Technical Information, P.O. Box 62, Oak Ridge, TN 37831; prices available from (615) 576-8401.

Available to the public from the National Technical Information Service, U.S. Department of Commerce, 5285 Port Royal Road, Springfield, VA 22161. 


\section{DISCLAIMER}

Portions of this document may be illegible in electronic image products. Images are produced from the best available original document. 


\title{
Savannah River Site Environmental Monitoring Plan
}

\author{
WSRC-3Q1-2, Volume 1 \\ Section 1000 Addendum \\ Revision 3
}

Environmental Protection Department November 1994

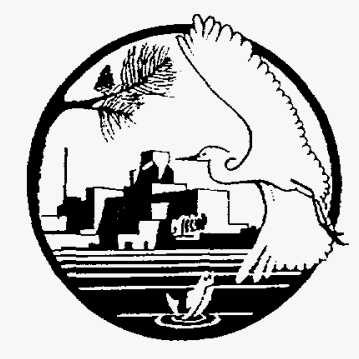




\section{Table of Contents}

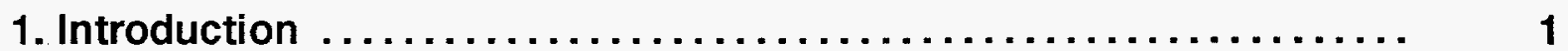

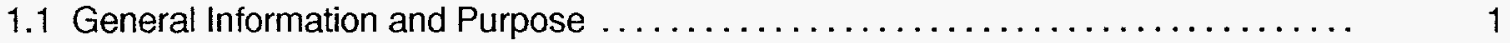

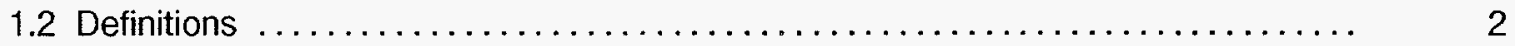

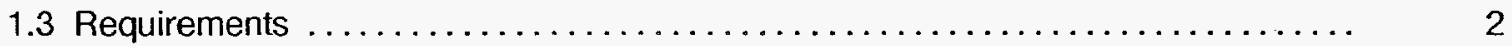

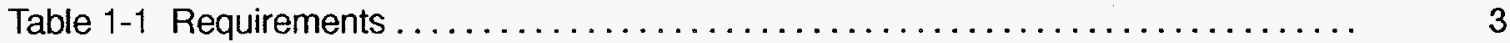

2. Liquid Effluent Monitoring $\ldots \ldots \ldots \ldots \ldots \ldots \ldots \ldots \ldots \ldots \ldots \ldots \ldots$

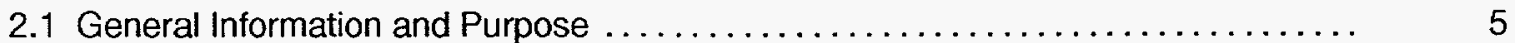

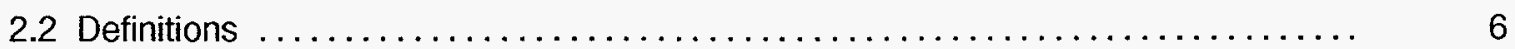

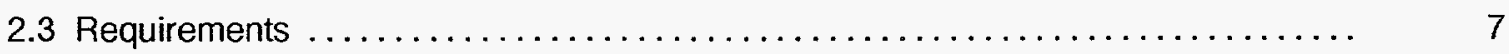

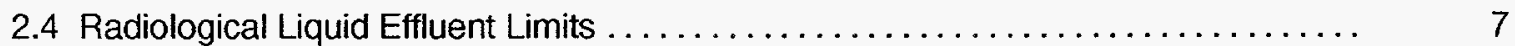

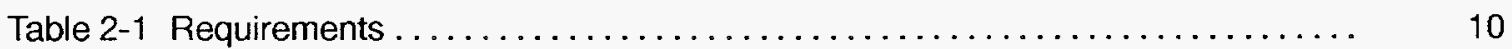

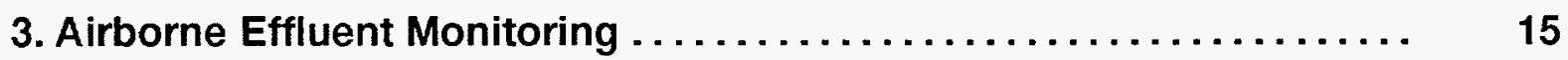

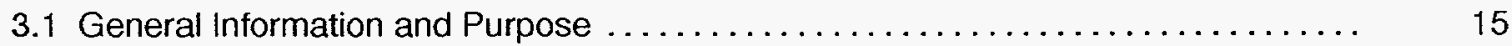

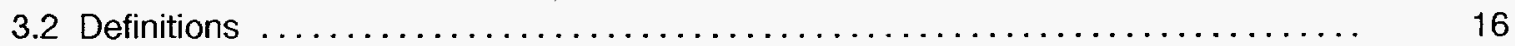

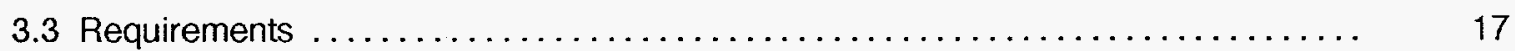

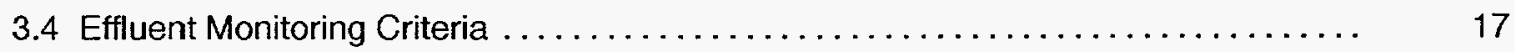

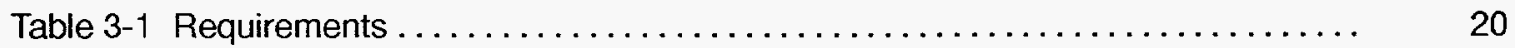

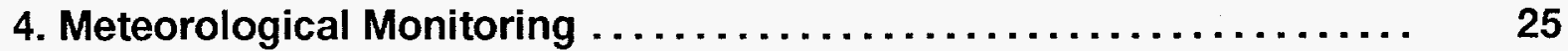

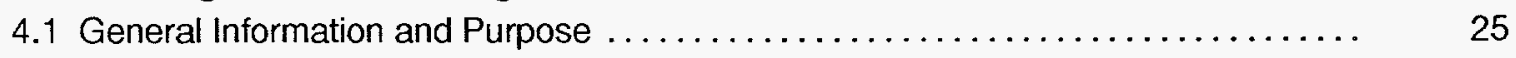

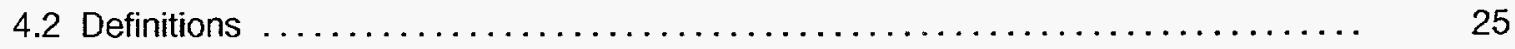

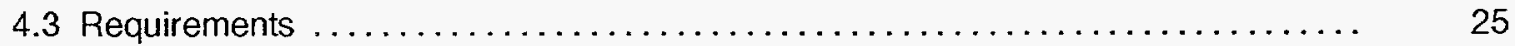

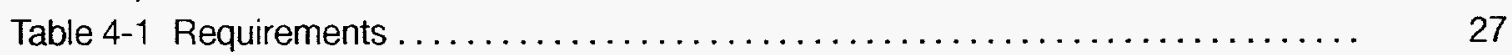

5. Environmental Surveillance ............................ 31

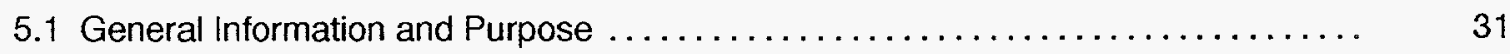

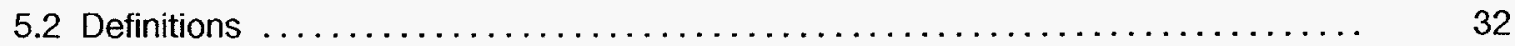

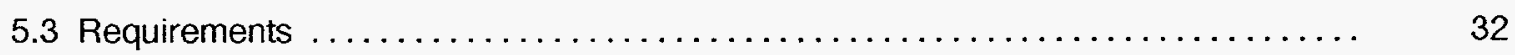

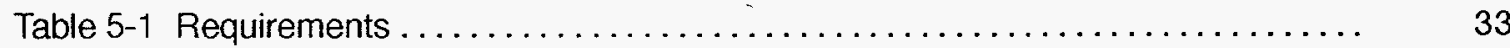

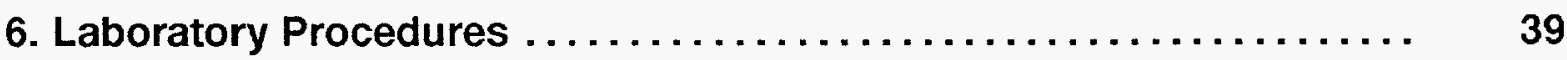

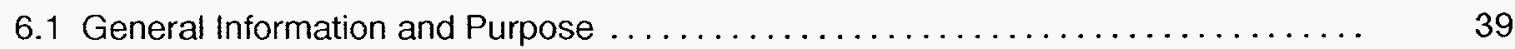

6.2 Definitions .................................................... 40

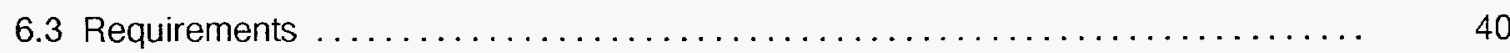

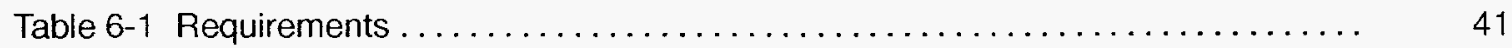

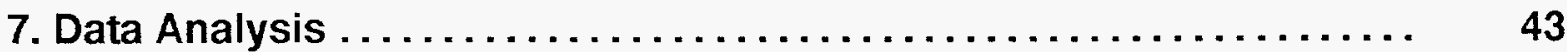

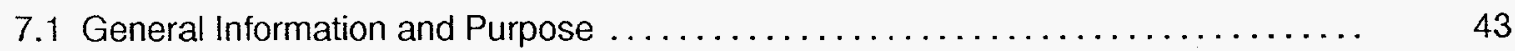

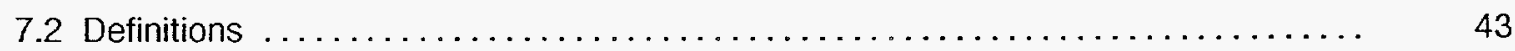

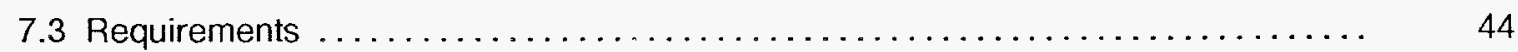

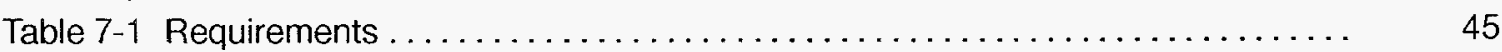




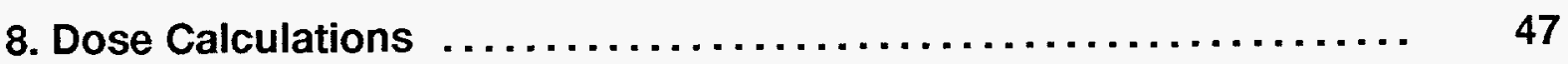

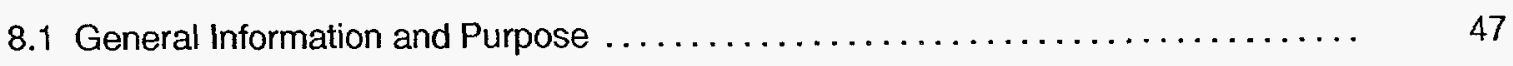

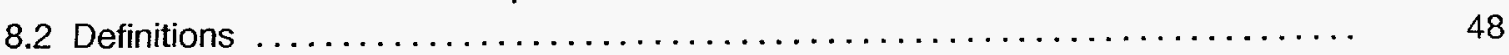

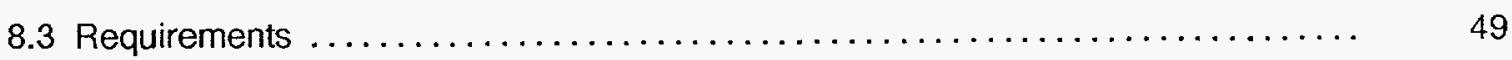

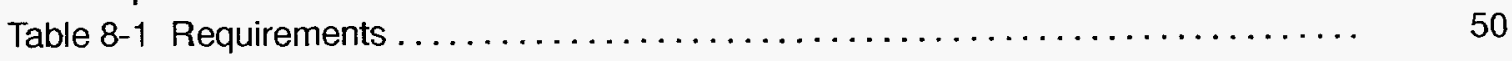

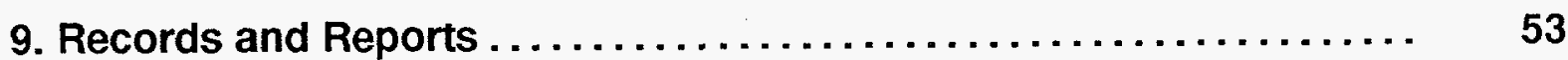

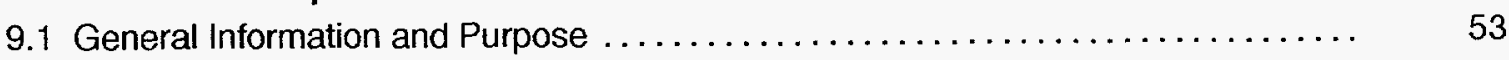

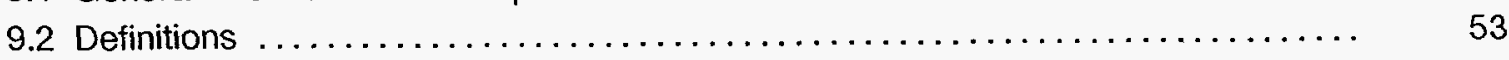

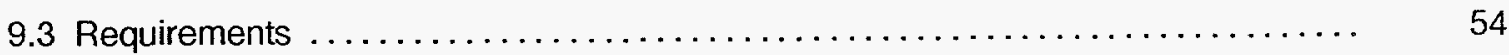

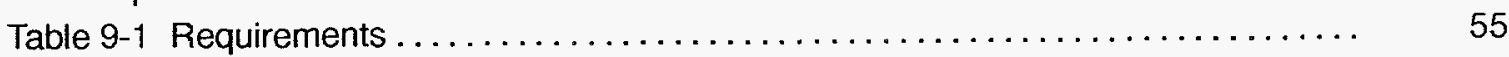

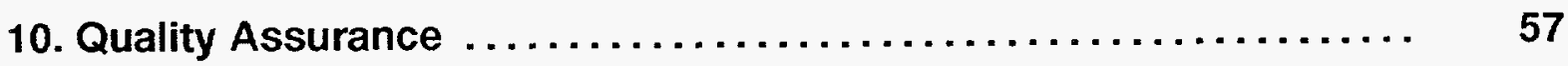

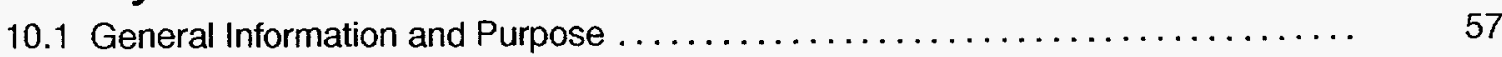

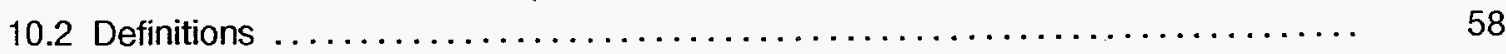

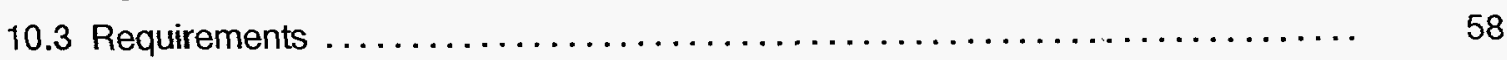

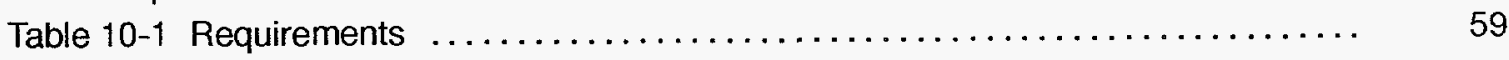

\section{References}

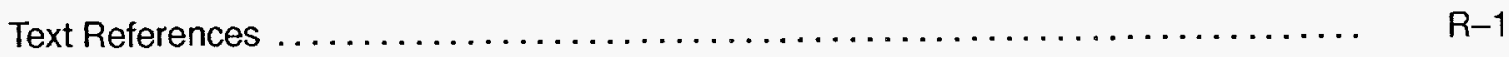




\section{Introduction}

\subsection{General Information and Purpose}

U.S. Department of Energy (DOE) Order 5400.1 [DOE, 1988] and 10 CFR 834, Radiation Protection of the Public and the Environment [DOE, 1993], require that an environmental monitoring plan be prepared for each DOE site. \{5400.1-IV(4) and 10 CFR 834.410 (f)\}

This document- the Savannah River Site Environmental Monitoring Plan (SRS EM Plan)—has been prepared according to guidance contained in the DOE 5400 Series orders, in $10 \mathrm{CFR} 834$, and in DOE/EH-0173T, Environmental Regulatory Guide for Radiological Effluent Monitoring and Environmental Surveillance [DOE, 1991].

The SRS EM Plan's purpose is to define the criteria, regulations, and guideline requirements with which SRS will comply. These criteria and requirements are applicable to environmental monitoring activities performed in support of the SRS Environmental Monitoring Program (SRS EM Program), WSRC-3Q1-2, Volume 1, Section 1100. They are not applicable to monitoring activities utilized exclusively for process monitoring/control.

The environmental monitoring program requirements documented in the SRS EM Plan incorporate all applicable should* requirements of DOE/EH-0173T and expand upon them to include nonradiological environmental monitoring program requirements.

The SRS EM Plan sets forth the following:

- required elements needed to determine compliance with 10 CFR 834 and other applicable federal environmental laws and regulations

- requirements for establishing the rationale and design criteria for each element

- requirements for determining the extent and frequency of monitoring and measurements

- requirements for establishing procedures for laboratory analyses

- requirements for establishing implementing procedures

- requirements for obtaining meteorological data

- requirements for performing a preoperational study for new or modified facilities

- required elements needed for quality assurance

- requirements for the preparation and disposition of reports and records \{5400.1-IV(4) and 10 CFR 834.410 (f.1 through f.7)\}

Sections 1101 through 1110 of the SRS EM Program will describe the effluent monitoring and environmental surveillance programs at SRS and will document the procedures, practices, and programs that implement the criteria and requirements set forth in the SRS EM Plan.

The Requirements tables of chapters 1 through 10 of this document state the environmental monitoring requirements that will be met at SRS. When implemented, the requirements will provide for effluent monitoring to obtain representative measurements of the quantities and concentrations of contaminants in liquid and airborne discharges and for environmental surveillance to monitor the 
effects, if any, of SRS activities on the public, on the environment, and on natural resources. \{5400.1-IV(4) and 10 CFR 834.410 (f)\}

The established requirements cover all major aspects of monitoring, sample analysis, data analysis, compliance demonstration, recordkeeping, reporting, and quality assurance. Any exemptions from these requirements will be noted and discussed. Noncompliance with these requirements will be documented in the SRS EM Program and addressed in the SRS EM Plan Corrective Action Plan, WSRC-ESH-EMS-94-0129. The Corrective Action Plan will contain a description of each deficiency, an action plan for correcting each deficiency, and a scheduled completion date for each action item.

DOE-SR will formally concur with the SRS EM Plan and the Corrective Action Plan. The SRS EM Plan will be reviewed annually and updated at least every 3 years. \{5400.1-IV(4)\} The SRS EM Program, which will contain detailed programmatic information that may be subject to frequent change, will be reviewed by DOE-SR but will not receive formal concurrence.

\subsection{Definitions}

- Environmental Monitoring - Environmental monitoring consists of two major activities: effluent monitoring and environmental surveillance.

- Effluent Monitoring - Effluent monitoring includes the continuous online measurement of liquid or airborne effluents (active monitoring) and the collection and analysis of samples from those effluents (passive monitoring) for the purpose of characterizing and quantifying contaminants in a process stream.

- Active Monitoring - Active monitoring consists of continuous online monitoring equipment from which real-time quantification of contaminant releases can be obtained. Kanne tritium monitors are an example of active monitoring.

- Passive Monitoring - Passive monitoring consists of continuous online sampling equipment from which samples must be collected, then analyzed, before quantification of radioactive releases can be determined. Air sample filters and proportional-flow liquid samplers are examples of passive monitoring equipment.

- Environmental Surveillance - Environmental Surveillance includes the collection and analysis of samples from environmental media and the measurement of external radiation to demonstrate compliance with applicable standards and to assess the effects, if any, on the site and surrounding environs.

\subsection{Requirements}

Table $1-1$, page 3 , itemizes the general environmental monitoring requirements and associated regulatory and/or guidance "drivers" with which SRS will comply. Where appropriate, specific interpretation and/or clarifying discussion of a requirement is provided. Unless otherwise noted, all requirements listed are applicable to radiological and nonradiological environmental monitoring programs.

Implementation of these requirements will be documented in the SRS EM Program. Any requirements not fully implemented will be included in the SRS EM Plan Corrective Action Plan. 


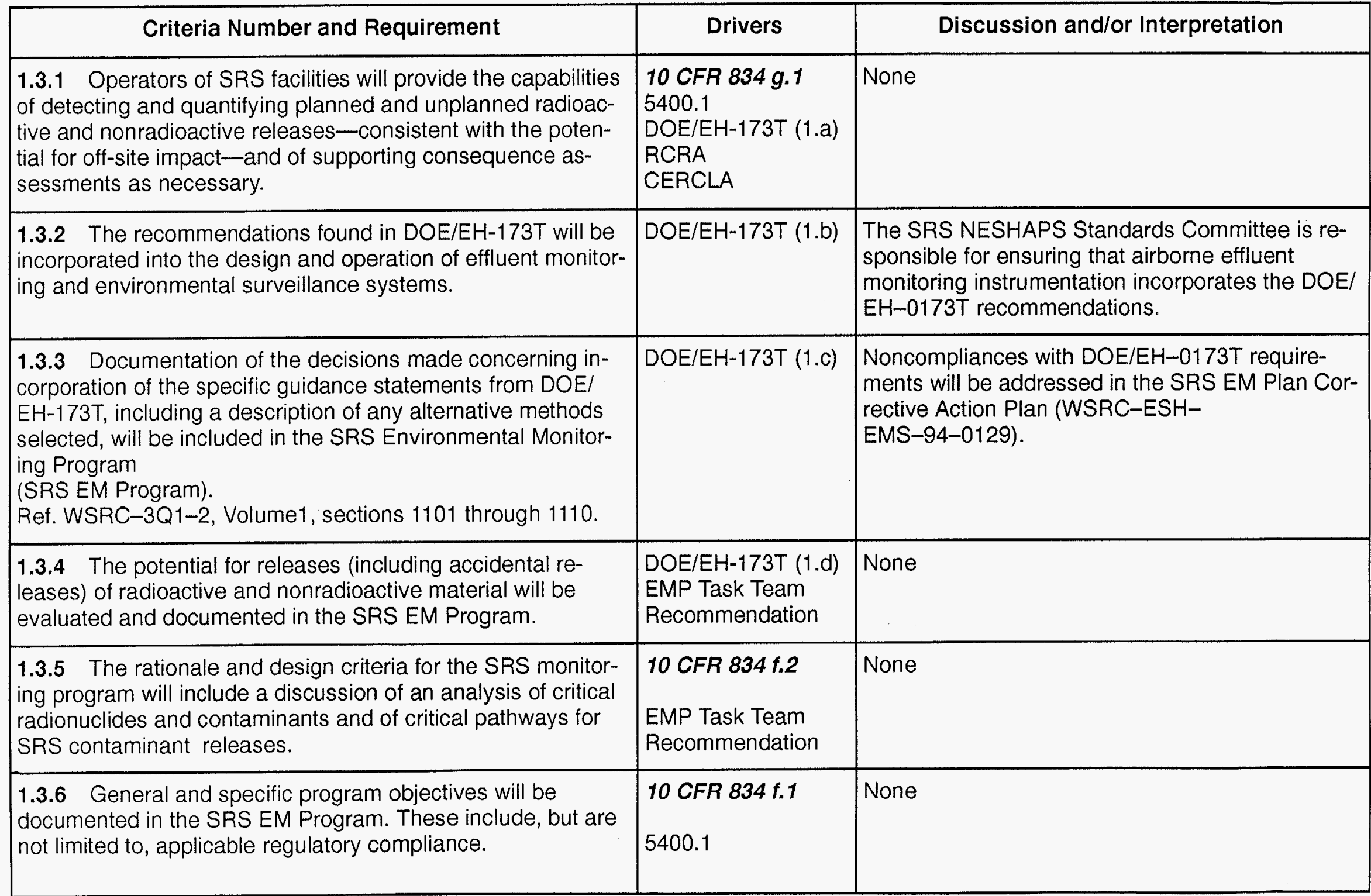




\section{Liquid Effluent Monitoring}

\subsection{General Information and Purpose}

The purpose of this chapter of the Savannah River Site Environmental Monitoring Plan (SRS EM Plan) is to define the liquid effluent monitoring criteria, regulations, and guideline requirements with which SRS will comply.

The following regulations, orders, and guidance documents contain the liquid effluent requirements are applicable to Savannah River Site (SRS) environmental liquid effluent monitoring activities:

- U.S. Department of Energy (DOE) Order 5400.1 [DOE, 1988]

- DOE Order 5400.5 [DOE, 1990]

- 10 CFR 834 [DOE, 1993]

- 40 CFR 141 [EPA, 1975]

- 40 CFR 136 [EPA, 1973b]

- South Carolina Department of Health and Environmental Control (SCDHEC) R. 61-9

- SCDHEC R. 61-81

- $\mathrm{DOE} / \mathrm{EH}$ - 0173T [DOE, 1991]

Although 40 CFR 191 does not contain specific effluent monitoring criteria, the data collected from the liquid effluent monitoring systems meeting the criteria in this document will be used as part of the compliance demonstration program. The dose limits outlined in 40 CFR 191 are imposed in 10 CFR 834.109(a) as part of radioactive waste management criteria.

Liquid effluent monitoring systems, both radiological and nonradiological, must provide representative measurements of the streams being monitored. To ensure such measurements, the effluent monitoring systems utilized at an emission point must:

- reflect the specific type and levels of contaminants present

- collect data at appropriate frequencies

- incorporate quality assurance measures at the collection and analysis phases [5400.1-IV(5.a.2)]:

A representative measurement program for liquid effluent monitoring is the basis for the requirements as contained in 10 CFR 834, and U.S. Department of Energy (DOE) Orders 5400.1 and 5400.5 and presented in Section 2.3. The representative measurements will provide acceptable data for meeting the following liquid effluent monitoring program objectives:

- Verify compliance with applicable federal, state, and local effluent regulations and DOE orders.

- Determine compliance with commitments made in Environmental Impact Statements, Environmental Assessments, or other official documents.

- Evaluate the effectiveness of effluent treatment. 
- Identify potential environmental problems and evaluate the need for remedial actions or mitigation measures.

- Support permit revision and/or reissuance.

- Detect, characterize, and report unplanned releases.

- Provide data to ensure that liquid releases remain ALARA. [5400.1-IV(5.a.1), 5400.5-I(8.a), and 10 CFR 834.201 (a.1)]

Implementation of this section of the SRS EM Plan will be detailed in the SRS Environmental Monitoring Program (SRS EM Program), WSRC-3Q1, Volume 1, Section 1102. Documentation to support compliance with the requirements in this section must be provided by the affected facility. The requirements do not apply to monitoring equipment utilized strictly for process monitoring.

A common misconception is that the Derived Concentration Guide (DCG) values contained in 5400.5 and 10 CFR 834 are effluent limits. This is not the case. DCG values are not necessarily considered "acceptable" discharge limits. They are provided to address the need to conduct BAT analyses and to aid in performing dose estimates. The ALARA provisions of $10 \mathrm{CFR} 834$ are applicable to all liquid discharges containing radioactive material derived from DOE operations, including those that are less than the DCG values and meet Best Available Technology (BAT) requirements. Radioactive waste streams that otherwise would contain radionuclide concentrations of more than the DCG reference values at the point of discharge to a surface waterway are required to implement BAT treatment to further reduce the concentration. BAT treatment also may be required for waste streams with concentrations of radionuclides that are less than the DCGs, if the waste streams do not conform to other specific requirements in 10 CFR 834. The subject of BAT is addressed further in the BAT Manual section of the Environmental Radiological Protection Program (ERPP), as required by 10 CFR 834.401 (d).

\subsection{Definitions}

Best Available Technology (BAT) - Best Available Technology means the preferred technology for a particular activity; it is selected from among others after taking into account factors related to technology, economics, public policy, and other parameters. The BAT is not a specific level of treatment, but is the conclusion of a selection process that includes several alternatives.

Derived Concentration Guide (DCG) - DCG means the concentration of a radionuclide in air or water that, under conditions of continuous exposure for one year by one exposure mode (i.e., ingestion of water, submersion in air, or inhalation), would result in an effective dose equivalent (EDE) of $100 \mathrm{mrem}, 0.1 \mathrm{rem}(1 \mathrm{mSv})$ to reference man. DCGs do not consider decay products when the parent radionuclide is the cause of the exposure.

Commence - Commence refers to the point in time at which an owner or operator undertakes a continuous program of construction or modification or enters into a contractual obligation to undertake and complete, within a reasonable time, a continuous program of construction or modification.

Continuous Effluent Monitoring - Continuous effluent monitoring is 1) characterization of the contaminant of concern by continuous sampling followed by laboratory analysis or 2) measurement by an online detector. For liquid effluents, a continuous sample can periodically collect an aliquot of the effluent stream.

Effective Dose Equivalent (EDE) - The EDE is the sum of the dose equivalents received by all organs or tissues of the body after each one has been multiplied by an appropriate weighting factor. 
The EDE includes the committed EDE from internal deposition of radionuclides and the EDE attributable to sources external to the body.

Effluent Monitoring - Effluent monitoring includes the continuous online measurement of liquid or airborne effluents (active monitoring) and the collection and analysis of samples from those effluents (passive monitoring) for the purpose of characterizing and quantifying contaminants in a process stream.

NPDES - National Pollutant Discharge Elimination System is a regulatory program for permitting liquid releases from facilities. Byproduct radioactive materials regulated under the Atomic Energy Act are excluded from NPDES permit requirements [40 CFR 122].

Online - An online measurement is made directly in real time. An online monitor could be located offline and the samples transported directly to a shielded detector.

Offline - Offline refers to a sample collected and transported for analysis.

Sampler - A sampler is a device used to collect samples from an effluent stream. It can deliver a sample to an online detector or preserve the sample for later laboratory analysis, such as silica gel sampling for tritium analysis.

\subsection{Requirements}

Table $2-1$, beginning on page 10 , itemizes the liquid effluent monitoring requirements and associated regulatory and/or guidance "drivers" with which SRS will comply. Where appropriate, specific interpretation and/or clarifying discussion of a requirement is provided. Unless otherwise noted, all requirements listed are applicable to radiological and nonradiological liquid monitoring programs. Implementation of these requirements will be documented in the SRS EM Program. Any requirements not fully implemented will be included in the SRS EM Plan Corrective Action Plan, WSRCESH-EMS-94-0129. Documentation to support compliance with these requirements must be supplied by the subject facility.

\subsection{Radiological Liquid Effluent Limits}

The following sections establish the liquid effluent release limits for discharge points. The liquid effluent monitoring systems must be of capable of detecting contaminants in SRS effluents to ensure compliance with these limits.

\subsubsection{Release Limits}

\subsubsection{Primary dose limit}

SRS will conduct activities so that the exposure of members of the public to radiation shall not cause an EDE greater than 100 mrem ( $1 \mathrm{mSv}$ ) per year from all sources and pathways of the activity and in combination with reasonably expected exposures from all other sources-excluding doses from radon and its decay products, doses received by a patient from medical sources of radiation used for diagnostic or therapeutic purposes, doses from consumer products, and doses from background radiation. [10 CFR 834.101(a.2)]

\subsubsection{Drinking Water}

Liquid releases from SRS activities shall not cause private or public drinking water systems downstream of the facility discharge to exceed the drinking water radiological limits in 40 CFR, Part 141. [10 CFR 834.103(a.5)] 


\subsubsection{DCG Limits}

SRS will conduct activities so that liquid releases of radioactive materials from the activities shall be treated by the BAT if any of the following conditions exist:

- The surface waters otherwise would contain, at the point of discharge to surface waters and prior to dilution, annual average concentrations of radioactive material greater than the DCG values listed in 10 CFR 834.

- The total annual EDE to the public would otherwise exceed $10 \mathrm{mrem}(0.1 \mathrm{mSv})$, with the liquid discharge contributing a significant portion of that dose.

- Operators are not in conformance with the Groundwater Protection Management Plan for the activity.

Note: For purposes of this section, if more than one type of radionuclide $A, B, \ldots N$ is present in concentrations $C_{A}, C_{B}, \ldots C_{N}$, and if the applicable DCGs are $D_{C G}, D_{C G}, \ldots D C G_{N}$, respectively, then the concentration shall be limited so that the following relationship exists:

$\left(\mathrm{C}_{\mathrm{A}} / \mathrm{DCG}_{\mathrm{A}}\right)+\left(\mathrm{C}_{\mathrm{B}} / \mathrm{DCG}_{\mathrm{B}}\right)+\ldots+\left(\mathrm{C}_{\mathrm{N}} / \mathrm{DCG}_{\mathrm{N}}\right) \leq 1$

where: $\mathrm{DCG}$ i is the derived concentration guide value for radionuclide $\mathrm{i}$.

Selection methods for a BAT alternative, along with approved schedules, will be contained in the BAT Plan as part of the Environmental Radiological Protection Program. [10 CFR 834.201(a.2) and 10 CFR 834.201(b) \& (c)]

\subsubsection{Settleable Solids}

Liquid release from SRS activities shall not result in the release of settleable solids to natural waterways if the concentration of radioactive material in the solids in the waste stream exceeds either or both of the following:

- i) $5 \mathrm{pCi}(0.2 \mathrm{~Bq})$ per gram of settleable solids for alpha-emitting radionuclides

- ii) $50 \mathrm{pCi}(2 \mathrm{~Bq})$ per gram of settleable solids for beta-gamma-emitting radionuclides [10 CFR 834.201(a.3)]

\subsubsection{Sanitary Sewers}

A DOE activity shall be conducted in a manner such that the concentration of radionuclides in liquid wastes discharged from the activity into sanitary sewerage shall:

- (1) be treated by the BAT to reduce the concentration level to less than five times the DCG values listed in 10 CFR 834 if the average monthly level otherwise would be greater than five times the DCG values at the point of discharge

- (2) not result in an annual discharge (above background) into public sewers in excess of $5 \mathrm{Ci}(200 \mathrm{GBq})$ of hydrogen-3; $1 \mathrm{Ci}(37 \mathrm{GBq})$ of carbon-14; or $1 \mathrm{Ci}$ (37 GBq) of all other radionuclides

- (3) be evaluated through pathway analyses or environmental surveillance to verify that the total annual discharge of radioactive material to the sanitary sewer system will not cause members of the public to receive incremental doses of more than 2 mrem per year from that source 
Note: The discharge of liquid wastes from an SRS activity into a chemical or sanitary sewerage system owned by the U.S. Government is not subject to requirements (1) and (2) if the system provides treatment according to an approved interim strategy prior to discharge of liquid wastes to surface waters, and if sludge from the system is disposed of according to all applicable federal regulations. [10 CFR 834.203]

\subsubsection{Native aquatic animal organisms}

SRS will conduct activities so that the absorbed dose to a native aquatic animal organism (e.g., fish, crustaceans, mollusks, and benthic invertebrates) shall not exceed 1 rad (0.01 gray) per day from exposure to radioactive material in liquid wastes discharged to natural waterways. [10 CFR 834.205]

\subsubsection{Groundwater protection}

SRS will conduct activities so that groundwater from radiological and nonradiological contamination is protected according to the Ground Water Protection Management Plan, which is contained in the ERPP [10 CFR 834.210]

\subsubsection{Reporting Limits}

SRS will submit to DOE

- a report that sets forth any release of radioactive materials or exposure to radiation that exceeds or potentially exceeds the limits established by 10 CFR 834 (listed above in section 2.4.2 for liquid releases), within one month of determination of the occurrence

- a report that sets forth any occurrence (including the release of property) that contributes or potentially contributes an annual EDE greater than 10 mrem or a collective EDE greater than 100 person-rem within one month of determination of the occurrence. [10 CFR 834.7(a.2) \& (a.3)] 


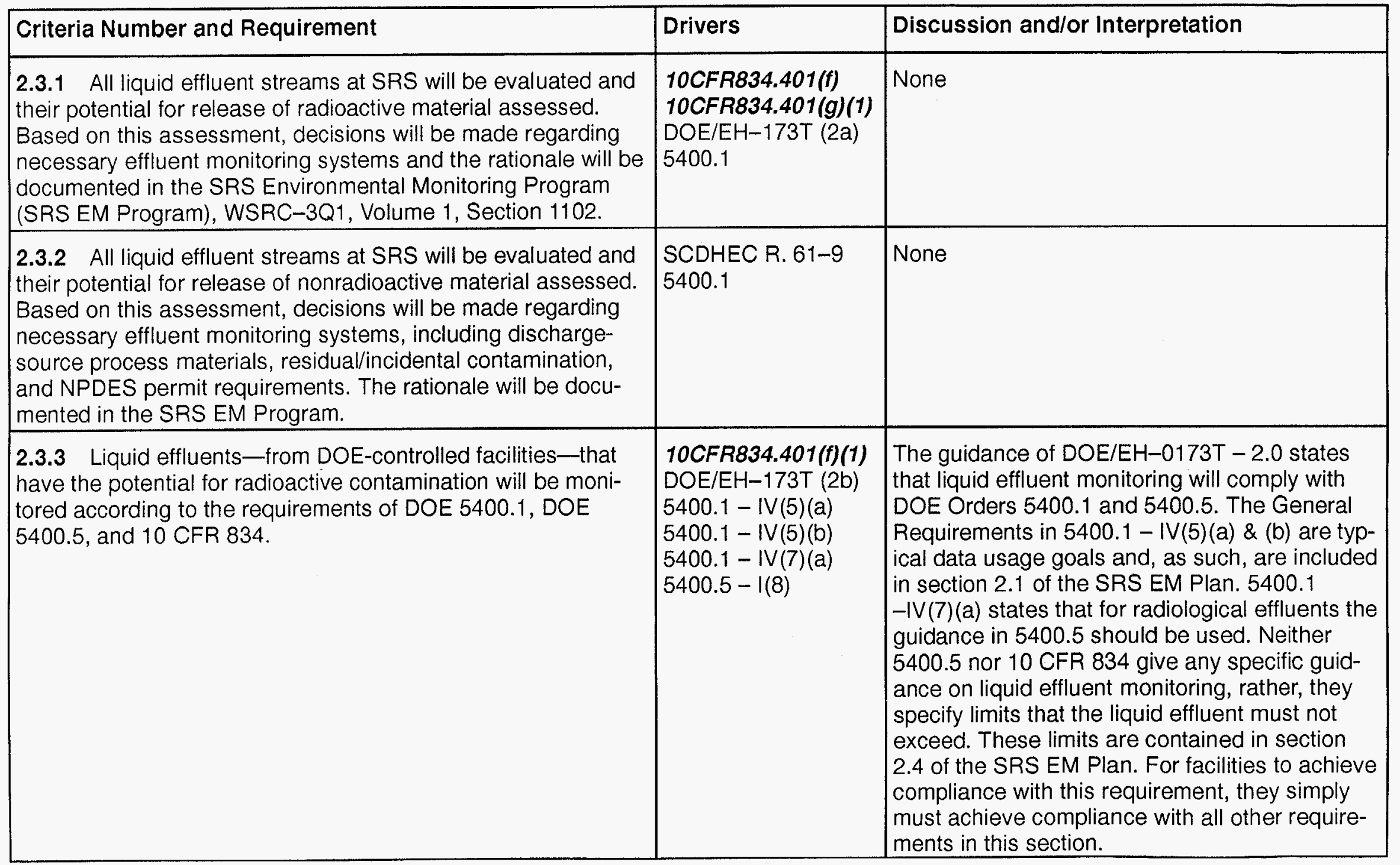




\section{Criteria Number and Requirement}

2.3.4 Facility operators will provide liquid waste stream monitoring adequate to demonstrate compliance with the requirements in Section 2.4 of DOE/EH-0173T; to quantify radionuclides released from each discharge point; to alert affected process supervisors of accidents in processes and emission controls; and to comply with the SRS NPDES permit requirements and conditions.

\begin{tabular}{|c|c|}
\hline rivers & Discussion and/or Interpretation \\
\hline $\begin{array}{l}\text { OCFR834.401(f)(1) } \\
\text { OCFR834.401(g)(1) } \\
\text { OE/EH-173T (2c) } \\
400.5-\|(1)(\mathrm{a}) \\
400.5-\|(1)(\mathrm{d}) \\
400.5-\|(3) \\
\text { CDHEC R.61-9 }\end{array}$ & $\begin{array}{l}\text { The guidance in DOE/EH-0173T (2c) states } \\
\text { that the monitoring must demonstrate com- } \\
\text { pliance with } 5400.5-11(2)(\mathrm{a}) \text {, which is an envi- } \\
\text { ronmental ALARA program requirement that will } \\
\text { be implemented through the SRS Environmen- } \\
\text { tal ALARA Program as outlined in the Environ- } \\
\text { mental Radiological Prevention Program } \\
\text { (ERPP). }\end{array}$ \\
\hline $\begin{array}{l}\text { OE/EH-173T (2.1) } \\
\text { CDHEC R. 61-9 }\end{array}$ & None \\
\hline $\begin{array}{l}\text { OE/EH-173T (2d) } \\
0 \text { CFR } 136 \\
\text { CDHEC R. } 61-81 \\
400.1-I V(5)(a)(2 c)\end{array}$ & $\begin{array}{l}\text { Flow measurements made for NPDES com- } \\
\text { pliance (nonradiological) are required by the } \\
\text { permit to be within } \pm 10 \% \text {. The same criteria } \\
\text { should be applied to radiological samples as } \\
\text { appropriate. [DOE/EH-0173T (2.3.2)] }\end{array}$ \\
\hline $\begin{array}{l}\mathrm{OE} / \mathrm{EH}-173 \mathrm{~T}(2 \mathrm{e}) \\
400.5-\mathrm{I}(8)(\mathrm{a})\end{array}$ & None \\
\hline
\end{tabular}

2.3.5 Continuous effluent monitoring with online detectors will be provided on release points that could exceed 1 times the DCG at the point of release over 1 year and are detectable with continuous detection devices or could result in unanticipated releases to the environment that could exceed 1 times the DCG averaged over 1 year and are detectable with continuous detection devices; or where required by the SRS NPDES permit.

2.3.6 When continuous monitoring or continuous sampling is provided, the overall accuracy of results will be determined ( $\pm \%$ accuracy and the \% confidence level) and documented in the SRS EM Program.

2.3.7 Provisions for monitoring liquid effluents during an emergency will be considered when determining routine liquid effluent monitoring program needs. 


\begin{tabular}{|l} 
Criteria Number and Requirement \\
\hline 2.3.8 The selection or modification of a liquid effluent moni-
\end{tabular}

toring system will be based on a careful characterization of the source(s), pollutant(s) (characteristics and quantities), sample collection system(s), treatment system(s), and final release point(s) of the effluents.
Drivers

10CFR834.401(f)(2) 10CFR834.401(f)(3) DOE/EH-0173T (2f) $5400.1-\operatorname{IV}(5)(\mathrm{a})(2 \mathrm{~b})$ SCDHEC R. $61-9$

\section{Discussion and/or Interpretation}

If possible, the sampling location should be based on pilot/preliminary studies at locations that isolate the source being assessed. Sampling locations for nonradiological contaminants should conform to the NPDES permit requirements as outlined in the SRS EM Program. For radiological effluents, the sample point should be selected to allow for the comparison of each facility effluent, prior to dilution, with the DCG values in 5400.5 (10 CFR 834, Appendix A), when practical. Economic, safety, and general access requirements should be taken into consideration, much like for BAT analysis, when selecting the sample points. As indicated by requirements 2.3.1 and 2.3.2, the rationale for sample-point selection will be included in the SRS EM Program.

2.3.9 For facilities with planned modifications that could increase effluent release quantity or affect quality or that could affect the sensitivity of monitoring or surveillance systems, a premodification assessment will be made and documented in the SRS EM Program. The premodification assessment will be conducted prior to commencing the modification and will determine the types and quantities of liquid emissions to be expected from the facility. It also will establish the associated liquid effluent monitoring needs of the facility. 


Criteria Number and Requirement

2.3.10 For all new facilities and new activities, a preoperational assessment will be made at least 1 year prior to startup. The assessment will a) characterize existing physical, chemical, and biological conditions that could be affected; b) establish background levels of radioactivity and, as appropriate, chemical components; c) characterize pertinent environmental parameters; d) identify potential pathways for human exposure and environmental impact; and e) determine the types and quantities of liquid effluents to be expected from the facility, and establish the associated liquid effluent monitoring needs.

2.3.11 The performance of the effluent monitoring systems will be sufficient to determine whether effluent releases of radioactive material are within the DCGs specified in DOE Order 5400.5 (10 CFR 834, Appendix A) and to comply with the reporting requirements in section 2.4.3 of this document

2.3.12 The required detection levels of the analysis and monitoring systems will be sufficient to demonstrate compliance with all regulatory requirements consistent with the characteristics of the contaminants that are present or expected to be present in the effluent.

2.3.13 Sampling systems will be sufficient to collect representative samples that provide for an adequate record of releases from a facility, to predict trends, and to quantify releases.

2.3.14 Continuous effluent monitoring and sampling system equipment will be calibrated before use and recalibrated any time they are subject to maintenance, modification, or system changes that may affect equipment calibration.

2.3.15 Sampling and monitoring systems will be recalibrated at least annually and routinely checked with known sources to

\begin{tabular}{|c|c|}
\hline Drivers & Discussion and/or Interpretation \\
\hline $\begin{array}{l}\text { 10CFR834.401(f)(7) } \\
\text { 10CFR834.401(j) } \\
\text { DOE/EH-0173T }(2 \mathrm{~g})\end{array}$ & None \\
\hline $\begin{array}{l}\text { 10CFR834.401(f)(1) } \\
\text { DOE/EH-173T (2h) } \\
5400.5-\|(7) \\
5400.5-\|(3)\end{array}$ & None \\
\hline $\begin{array}{l}\text { 10CFR834.401 }(g)(3) \\
\text { DOE/EH-0173T (2i) } \\
5400.1-\operatorname{IV}((8)(\mathrm{c}) \\
5400.5-\mid(8) \\
\text { SCDHEC R. } 61-9\end{array}$ & $\begin{array}{l}\text { The regulatory requirements are contained in } \\
\text { Section } 2.4 \text { of this document. }\end{array}$ \\
\hline $\begin{array}{l}\text { 10CFR834.401(g)(2) } \\
\text { DOE/EH-173T (2j) } \\
5400.1-\operatorname{IV}(5)(\mathrm{a})(2) \\
\end{array}$ & None \\
\hline DOE/EH-173T (2k) & $\begin{array}{l}\text { This requirement is limited to M\&TE equipment, } \\
\text { as outlined in the SRS Quality Assurance Pro- } \\
\text { gram. }\end{array}$ \\
\hline DOE/EH-173T (2I) & $\begin{array}{l}\text { This requirement is limited to M\&TE equipment, } \\
\text { as outlined in the SRS Quality Assurance Pro- } \\
\text { gram. }\end{array}$ \\
\hline
\end{tabular}




\begin{tabular}{|c|c|c|}
\hline Criteria Number and Requirement & Drivers & Discussion and/or Interpretation \\
\hline $\begin{array}{l}\text { 2.3.16 Environmental conditions (e.g., temperature, humidity, } \\
\text { radiation level, dusts, and vapors) will be considered when lo- } \\
\text { cating effluent monitoring systems to avoid conditions that can } \\
\text { influence the system operations. }\end{array}$ & DOE/EH-173T (2m) & None \\
\hline $\begin{array}{l}\text { 2.3.17 Offline liquid transport lines will be replaced if they be- } \\
\text { come contaminated with radioactive materials to the point } \\
\text { where the sensitivity of the system is affected or if they be- } \\
\text { come ineffective in meeting the design basis within the estab- } \\
\text { lished accuracy/confidence levels. }\end{array}$ & DOE/EH-173T (2n) & None \\
\hline $\begin{array}{l}\text { 2.3.18 If continuous monitoring/sampling and recording of the } \\
\text { effluent quantity (stream flow) is not feasible for a specific efflu- } \\
\text { ent stream, the extenuating circumstances will be documented } \\
\text { in the SRS EM Program. }\end{array}$ & DOE/EH-173T (20) & None \\
\hline $\begin{array}{l}\text { 2.3.19 Sampling/monitoring lines and components will be de- } \\
\text { signed to be compatible with the chemical and biological na- } \\
\text { ture of the liquid effluent. }\end{array}$ & DOE/EH-173T (2p) & None \\
\hline $\begin{array}{l}\text { 2.3.20 The output signal instrumentation, monitoring system } \\
\text { recorders, and alarms will be in a location that is continuously } \\
\text { occupied by operations or security personnel. }\end{array}$ & DOE/EH-173T (2q) & None \\
\hline $\begin{array}{l}\text { 2.3.21 To signal the need for corrective actions that may be } \\
\text { necessary to prevent public or environmental exposures from } \\
\text { exceeding the limits or recommendations given in Section } 2.4 \\
\text { of this document, when continuous monitoring systems are re- } \\
\text { quired, will have alarms set to provide timely warnings. }\end{array}$ & DOE/EH-173T (2r) & $\begin{array}{l}\text { Conditions requiring the use of continuous mon- } \\
\text { itoring systems are presented in Requirement } \\
2.3 .5 \text {. }\end{array}$ \\
\hline $\begin{array}{l}\text { 2.3.22 As they apply to the liquid effluents, the general quality } \\
\text { assurance program requirements identified in Chapter } 10 \\
\text { ("Quality Assurance") of this document will be followed. }\end{array}$ & DOE/EH-173T (2s) & None \\
\hline
\end{tabular}




\section{Airborne Effluent Monitoring}

\subsection{General Information and Purpose}

The purpose of this chapter of the Savannah River Site Environmental Monitoring Plan (SRS EM Plan) is to define the airborne effluent monitoring criteria, regulations, and guideline requirements with which SRS will comply.

The following regulations, orders and guidance documents contain the airborne effluent requirements applicable to SRS environmental monitoring activities:

- U.S. Department of Energy (DOE) Order 5400.1 [DOE, 1988]

- DOE Order 5400.5 [DOE, 1990]

- 10 CFR 834 [DOE, 1993]

- 40 CFR 60 [EPA, 1973a]

- 40 CFR 61 [EPA, 1989]

- South Carolina Department of Health and Environmental Control (SCDHEC) R.61-62 [SCDHEC, 1976]

- DOE/EH - 0173T [DOE, 1991]

Although 40 CFR 191 does not contain specific effluent monitoring criteria, the data collected from the airborne effluent monitoring systems meeting the criteria in this document will be used as part of the compliance demonstration program. The dose limits outlined in 40 CFR 191 are imposed in 10 CFR 834.102(a) as part of radioactive waste management criteria.

Airborne effluent monitoring systems, both radiological and nonradiological, will provide representative measurements of the air streams being monitored. To ensure representative measurements, the effluent monitoring systems utilized at an emission point will [5400.1-IV(5.a.2)]

- reflect the specific type and levels of contaminants present

- collect data at appropriate frequencies

- incorporate Quality Assurance measures at the collection and analysis phases

A representative-measurement program for airborne effluent monitoring is the basis for the requirements contained in 10 CFR 834, and DOE Orders 5400.1 and 5400.5 and presented in Section 3.3. The representative measurements will provide acceptable data for meeting the following airborne effluent monitoring program objectives: [5400.1-IV(5.a.1) \& 5400.5-I(8.a)]

- Verify compliance with applicable federal, state, and local effluent regulations and with DOE orders.

- Determine compliance with commitments made in Environmental Impact Statements, Environmental Assessments, or other official documents.

- Evaluate the eifectiveness of effluent treatment.

- Identify potential environmental problems and evaluate the need for remedial actions or mitigation measures. 
- Support permit revision and/or reissuance.

- Detect, characterize, and report unplanned releases.

- Provide data to ensure that airborne releases remain ALARA. [10 CFR 834.109 (a.1)]

\subsection{Definitions}

- Commence-Commence refers to the point at which an owner or operator undertakes a continuous program of construction or modification or enters a contractual obligation to undertake and complete, within a reasonable time, a continuous program of construction or modification.

- Continuous Effluent Monitoring - Continuous effluent monitoring is characterization of the contaminant of concern by continuous sampling, followed by laboratory analysis or by an online detector measurement.

- Continuous Flow Monitoring - Continuous flow monitoring is a process in which an installed flow sensing system gives real-time flow rates. Examples: hot-wire anemometers, annubar systems, etc.

- Effective Dose Equivalent (EDE) - The effective dose equivalent is the sum of the dose equivalents received by all organs or tissues of the body after each one has been multiplied by an appropriate weighting factor. The effective dose equivalent includes the committed effective dose equivalent from internal deposition of radionuclides and the effective dose equivalent attributable to sources external to the body.

- Effluent Monitoring - Effluent monitoring includes the continuous online measurement of liquid or airborne effluents (active monitoring) and the collection and analysis of samples from those effluents (passive monitoring) for the purpose of characterizing and quantifying contaminants in a process stream.

- Emission Point - Emission point is a designated point of emissions, such as a stack, vent, area source, etc. Includes both point and diffuse sources.

- Diffuse Source - Diffuse source is any source that does not emit through a point source.

- Maximally Exposed Individual - A maximally exposed individual is a member of the public-at any off-site point where there is a residence, school, business or office-who receives the highest effective dose equivalent from airborne emissions attributable to SRS activities.

- Normal Operational Emissions - The emissions from a source when it is operating at 100 percent of the allowed facility operations. If a facility can operate at only 30 percent of the normal design rate because of a physical limitation, the emissions at the 30-percent level will be considered the normal operational emissions. Administrative controls that limit a facility's design operational capacity will be considered on a case-by-case basis.

- Online Detector - An online detector is a measurement device that gives a direct real-time readout of the contaminants and/or levels of contaminants in the air stream being monitored. Examples: Kanne chamber or opacity monitor.

- PEDE - Potential effective dose equivalent is the potential to emit expressed in terms of effective dose equivalent.

- Point Source - A point source is a well-defined single exhaust point, such as a stack or vent. 
- Potential to Emit - Those emissions that would result if all control devices were removed and emissions were otherwise normal at maximum operating levels.

- Sampler - A sampler is a device used to collect samples from an effluent stream. It can deliver a sample to an online detector or preserve the sample for later laboratory analysis, such as silica gel sampling for tritium analysis.

\subsection{Requirements}

Table $3-2$, beginning on page 20 , itemizes the airborne effluent monitoring requirements and associated regulatory and/or guidance "drivers" with which SRS will comply. Where appropriate, specific interpretation and/or clarifying discussion of a requirement is provided. Unless otherwise noted, all requirements listed are applicable to radiological and nonradiological airborne monitoring programs.

Implementation of these requirements will be documented in the SRS Environmental Monitoring Program (SRS EM Program), WSRC-3Q1, Volume 1, Section 1103. Any requirements not fully implemented will be included in the SRS Environmental Monitoring Corrective Action Plan, WSRCESH-EMS-94-0129. Documentation to support compliance with these requirements will be supplied by the subject facility. The requirements do not apply to monitoring equipment utilized strictly for process monitoring.

\subsection{Effluent Monitoring Criteria}

The following sections establish the minimum airborne effluent monitoring system criteria for an emission point. These requirements satisfy the criteria contained in 40 CFR 61.93, as agreed to with Region IV of the U.S. Environmental Protection Agency (EPA) [40 CFR 61.93(b)]. Note: Agreements are documented in the Rad NESHAP Quality Assurance Project Plan, WSRC-IM-91-60. Other methods may be used after receiving prior EPA approval. [40 CFR 61.93(b.3)]

\subsubsection{Selection of Point-Source Sampling Sites}

The location of a sampling site directly affects the degree to which a representative sample can be collected. Sites will be selected to maximize the distance from flow disturbances. Sampling sites will be selected such that a minimum of 2 duct diameters downstream and 0.5 duct diameters upstream of any flow disturbance is maintained. When practical and for new facilities, this requirement will be expanded to at least 5 duct diameters downstream and 2 duct diameters upstream of a flow disturbance. For rectangular or square ducts, the equivalent duct diameter $\left(D_{e}\right)$ will be used. The equivalent duct diameter is found as

$$
D_{e}=\frac{2 \times \text { length } \times \text { width }}{(\text { length }+ \text { width })}
$$

[40 CFR 61.93(b)(2)(i)]

\subsubsection{General Radionuclide Monitoring from Point Source}

Table 3-1, page 18, shows requirements that satisfy the following 40 CFR 61.93 criteria: (b.1), (b.2.ii), (b.4.i). These requirements are applicable to all radionuclide sampling from point sources. Additional monitoring requirements for specific radionuclides are contained in Section 3.4.3. 
Table 3-1 Requirements That Satisfy Certain 40 CFR 61.93 Criteria

Potential to Emit
(mrem/yr PEDE)

1) Continuous effluent monitoring for radionuclides contributing at
least 10 percent of the emission point's PEDE.
2) Particulate sampling, if required, will be conducted isokinetically
with a tolerance of \pm 10 percent.
3) If effluent flows vary by more than 10 percent annually, continuous
flow monitoring will be used. For emission points with flow varia-
tions of $<10$ percent, EPA Method 2 ( 40 CFR 60 ) can be used at a
specified frequency.
4) Conduct periodic confirmatory measurements for radionuclides
contributing < 10 percent of the emission point's PEDE.
1) Continuous proportional effluent monitoring may be performed. If
isokinetic sampling is conducted, it will be maintained at \pm 20 per-
cent.
2) Annual grab samples may be collected in place of continuous pro-
portional effluent monitoring; however, grab samples must be col-
lected during steady-state conditions.
3) For emission points existing prior to 1994 , measurement frequency
must conform to that outlined by EPA and contained in the appen-
dices of the Rad NESHAP Quality Assurance Project Plan,
WSRC-IM- $91-60$. If the emission point is not listed, items 1 and 2
above will apply.
4) Effluent flow rates can be determined by continuous methods or by
EPA Method 2 .
1) Effluent monitoring is not required, but emissions must be deter-
mined based on process knowledge or on another method that can
be documented.
2) For emission points existing prior to 1994 , measurement frequency
must conform to that outlined by EPA and contained in the appen-
dices of the Rad NESHAP Quality Assurance Project Plan. If the
emission point is not listed, item 1 above will apply.

\subsubsection{Specific-Radionuclide Monitoring and Sample Collection Methods}

The following methods will be followed for specific radionuclides when they will be sampled and monitored [40 CFR 61.93(b.2.iii)]. Other methods, as approved by EPA, may be used with prior approval. These requirements are in addition to the general methods in Section 3.4.2.

\subsubsection{Particulates}

Particulates will be collected on filter media that are highly efficient at removing submicron particles. The guidance in ANSI N13.1 [ANSI, 1969] will be followed in selecting filter media. 


\subsubsection{Tritium}

Tritium in the form of water vapor will be collected either by sorption, condensation or dissolution techniques. Appropriate collection media include silica gel, molecular sieves, ethylene glycol bubbles, and water bubbles.

Tritium in gaseous form may be measured directly with a Kanne Chamber if it is known that the sample contains only tritium or if the isotopic ratio of the radionuclides in the sample is well known. The tritium in the sample also may be oxidized into tritium oxide-using a metal catalyst-and collected as appropriate.

There is no need to sample in an isokinetic manner as long as the tritium is not in a particulate form.

\subsubsection{3 lodines}

Iodines will be collected by sorption or dissolution techniques. Appropriate collection media include charcoal, impregnated charcoal, metal zeolites, and caustic solutions.

\subsubsection{Argon, Krypton, and Xenon}

Radionuclides of these elements will be measured directly by online detectors, collected in gas-sampling flasks for laboratory analysis, or collected by low-temperature sorption techniques. Appropriate absorbers are charcoal and metal zeolites.

\subsubsection{Oxygen, Carbon, Nitrogen, and Radon}

Radionuclides of these elements will be measured directly with online detectors. Radionuclides of carbon in the form of carbon dioxide may be collected by dissolution in caustic solutions.

\subsubsection{Tracer Gas Flow-Monitoring Techniques}

In some instances, it is impractical to measure flow with 40 CFR 60 Method 2. In these cases, prior EPA approval can be obtained to utilize tracer gas techniques. An example of this application is a stack where routine access by test personnel to an acceptable sampling site is not available. The tracer gas can be injected at some location in the facility and sampled via normal sampling systems.

\subsubsection{Radiological Diffuse-Source Emissions}

Airborne emissions from diffuse sources do not require specific monitoring systems. Estimated emissions will be calculated from data collected for personnel protection and/or process knowledge. Implementation of this requirement will be documented in the SRS EM Program.

\subsubsection{Nonradiological Emissions - Point and Diffuse Sources}

The monitoring requirements will be determined based on the applicable regulatory requirements and permit conditions. At this time, the regulations are changing to accommodate the 1990 Clean Air Act Amendments. Implementation of this requirement will be documented in the SRS EM Program. 


\begin{tabular}{|c|c|c|}
\hline Criteria Number and Requirement & Drivers & Discussion and/or Interpretation \\
\hline $\begin{array}{l}\text { 3.3.2 Nonradiological emissions from SRS operations will be } \\
\text { evaluated. Based on this assessment, decisions will be made } \\
\text { regarding necessary effluent monitoring systems, and the ra- } \\
\text { tionale will be documented in the Environmental Monitoring } \\
\text { Program. }\end{array}$ & $\begin{array}{l}5400.1 \\
\text { SCDHEC 61-62 }\end{array}$ & None \\
\hline $\begin{array}{l}\text { 3.3.3 Airborne emissions from SRS facilities that have a po- } \\
\text { tential to emit exceeding } 0.1 \mathrm{mrem} / \mathrm{yr} \text { (effective dose equiva- } \\
\text { lent) to a member of the public under realistic exposure condi- } \\
\text { tions will be monitored accordaing to the requirements of } 40 \\
\text { CFR } 61 \text {. }\end{array}$ & $\begin{array}{l}\text { 10CFR834.401(f)(1) } \\
\text { DOE/EH-0173T (3b) } \\
40 \text { CFR } 61, \text { Subpart } \\
\text { H } \\
5400.1-\operatorname{IV}(7)(\mathrm{a}) \\
5400.5-\operatorname{II}(\mathrm{b})(1)\end{array}$ & $\begin{array}{l}\text { The guidance of DOE/EH-01173T - } 3.0 \text { states } \\
\text { that airborne monitoring will comply with DOE } \\
\text { Orders } 5400.1 \text { and } 5400.5 \text {. These orders simply } \\
\text { require that the monitoring comply with } 40 \text { CFR } \\
61 \text { [ } 5400.1-I V(7)(\text { a) and } 5400.5-I I(b)(1)] \text {. As } \\
\text { such, this requirement only reflects the need to } \\
\text { comply with } 40 \text { CFR } 61 \text {, Subpart } H \text {, which is } \\
\text { where the monitoring requirements associated } \\
\text { with SRS activities are located. The specific re- } \\
\text { quirements of } 40 \text { CFR } 61 \text {, Subpart } H \text {, are in- } \\
\text { cluded in requirements } 3.3 .1,3.3 .4,3.3 .13 \text {, } \\
3.3 .16 \text { and } 3.3 .21 \text {. }\end{array}$ \\
\hline $\begin{array}{l}\text { 3.3.4 The minimum criteria for monitoring is contained in } \\
\text { Section } 3.4 \text { of this document }\end{array}$ & $\begin{array}{l}\text { 10CFR834.401(g)(2) } \\
\text { DOE/EH-0173T (3c) } \\
40 \text { CFR } 61.93 \\
5400.1-\operatorname{IV}(7)(\mathrm{a})(1) \\
5400.1-\operatorname{IV}(8)(\mathrm{a})(1)\end{array}$ & None \\
\hline
\end{tabular}




\begin{tabular}{|l} 
Criteria Number and Requirement \\
3.3.5 For facilities with planned modifications that could in-
\end{tabular}
crease effluent release quantity or quality or that could affect the sensitivity of monitoring or surveillance systems, a premodification assessment will be made and documented in the Environmental Monitoring Program. The premodification assessment will be conducted prior to commencing the modification and will determine the types and quantities of airborne emissions to be expected from the facility. It also will establish the associated airborne emission monitoring needs of the facility.

3.3.6 For all new facilities, a preoperational assessment will be completed at least one year prior to startup. The assessment will a) characterize existing physical, chemical, and biological conditions that could be affected; b) establish background levels of radioactivity and, as appropriate, chemical components; c) characterize pertinent environmental parameters; d) identify potential pathways for human exposure and environmental impact; e) determine the types and quantities of airborne emissions to be expected from the facility; and f) establish the associated airborne emission monitoring needs of the facility.

3.3.7 The performance of the airborne emissions monitoring systems will be sufficient for determining whether the releases of radioactive materials are within the following limits: a) less than $10 \mathrm{mrem} / \mathrm{yr}$ effective dose equivalent from all site activities to the maximally exposed individual (dose determined with CAP-88), excluding dose from radon and its decay daughter products and from background; b) average radon-222 flux rates of less than $20 \mathrm{pCi}(0.7 \mathrm{~Bq}) / \mathrm{m}^{2} / \mathrm{sec}$ where radium-226 residues are accepted for storage; and $c$ ) outdoor boundary concentrations of less than $3 \mathrm{pCi}(0.1 \mathrm{~Bq}) / \mathrm{L}$ radon above background at facilities where significant sources of radon are handled.
Drivers

DOE/EH-0173T (3d) 40 CFR 61.96

SCDHEC 61-62

10CFR834.401(f)(7) 10CFR834.401(j) DOE/EH-0173T (3d) 40 CFR 61.96 10CFR834.102(a)(2)
10CFR834.102(a)(3) 10CFR834.102(a)(4) 10CFR834.102(f)(1) DOE/EH-0173T (3e) 40 CFR 61.92 $5400.5-11(1)(b)$ $5400.5-11(1)(b)(1)$

Although not related to monitoring, should the preoperational assessment determine that actual emissions from the facility as a result of the modification exceed $0.1 \mathrm{mrem} / \mathrm{yr}$, an "Approval to Construct or Modify" must be obtained from EPA prior to commencing the activity. Therefore, Item \#e of the preoperational assessment will be completed before the activity is commenced.

This criteria is not intended to implement the 10 CFR 834.102(a)(1) requirement for ALARA.

This criteria is demonstrated through the SRS ALARA program. The airborne effluent monitors only provide data, which is used to demonstrate that ALARA is being practiced by a facility and to indicate the need for corrective actions. The actions taken to reduce emissions would be the ALARA process at work.

Requirement 10 CFR $834.102(a)(5)$ is from 40 CFR 192 and is applicable only to Uranium Mill Tailing Sites, of which SRS is not one. 


Criteria Number and Requirement
3.3.8 The performance of the airborne emissions monitoring
systems will be sufficient for determining whether the releases
of nonradioactive materials are within federal and state limits
and meeting the specific requirements of SCDHEC $61-62$
Regulation 62.5 standards.

3.3.9 Effluent monitoring equipment will be calibrated before use and recalibrated any time it is subject to maintenance or modification that may affect equipment calibration.

3.3.10 Effluent monitoring equipment will be recalibrated at least annually and checked routinely with known sources or standards to determine if it is consistently functioning properly.

3.3.11 Continuous-flow-monitoring systems utilized for environmental effluent monitoring will be calibrated annually with a method that meets the criteria of Appendix E of 40 CFR 52, with exceptions as granted by EPA.

\begin{tabular}{|c|c|}
\hline Drivers & Discussion and/or Interpretation \\
\hline $\begin{array}{l}5400.1-\operatorname{IV}(8)(a)(1) \\
\text { SCDHEC 61-62 }\end{array}$ & $\begin{array}{l}\text { As with radiological emissions, this criteria can } \\
\text { be achieved with calculations and process } \\
\text { knowledge, at least until a regulation requires } \\
\text { some form of monitoring. The monitoring re- } \\
\text { quirements would be those outlined in Section } \\
3.4 \text {. }\end{array}$ \\
\hline $\begin{array}{l}\text { 10CFR834.401(g)(2) } \\
\text { DOE/EH-0173T (3f) } \\
40 \text { CFR } 60 \text { App. B } \\
40 \text { CFR } 61 \text { App. B }\end{array}$ & $\begin{array}{l}\text { This requirement is limited to M\&TE equipment, } \\
\text { as outlined in the SRS Quality Assurance Pro- } \\
\text { gram. }\end{array}$ \\
\hline $\begin{array}{l}\text { 10CFR834.401(g)(2) } \\
\text { DOE/EH-0173T (3g) } \\
40 \text { CFR } 60 \text { App. B } \\
\text { 40 CFR } 61 \text { App. B }\end{array}$ & $\begin{array}{l}\text { This requirement is limited to M\&TE equipment, } \\
\text { as outlined in the SRS Quality Assurance Pro- } \\
\text { gram. }\end{array}$ \\
\hline EPA Agreement & $\begin{array}{l}\text { The approved flow-measurement methods out- } \\
\text { lined in the requirements of } 40 \text { CFR } 61.93(\mathrm{~b})(1) \\
\text { are not continuous methods, but under some } \\
\text { circumstances, flow must be monitored continu- } \\
\text { ously [ } 40 \text { CFR } 61.93(\mathrm{~b})(1)(\mathrm{iii}) \text { ]. As such, EPA's } \\
\text { Region IV has granted SRS approval to use } \\
\text { continuous-flow-monitoring methods (i.e., hot- } \\
\text { wire anemometers, annubars, etc.), subject to } \\
\text { initial calibration with methods in } 40 \text { CFR } 52 \text {, } \\
\text { Appendix E. In addition, until approved for re- } \\
\text { duced-frequency requirements, the relative ac- } \\
\text { curacy portion of the test in } 40 \text { CFR } 52 \text {, Appen- } \\
\text { dix E, must be conducted each calendar quar- } \\
\text { ter. EPA also has approved, on a case-by-case } \\
\text { basis, the use of tracer gas techniques in lieu of } \\
\text { the pitot tube methods for this testing. }\end{array}$ \\
\hline
\end{tabular}




Criteria Number and Requirement

3.3.12 Provisions for effluent monitoring of airborne emissions during accident situations will be considered when determining routine airborne emission monitoring program needs.

3.3.13 New or modified airborne effluent monitoring equipment will be designed to meet in-leakage testing of less than 0.01 $\mathrm{cfm}$ or 0.5 percent of normal flow, whichever is higher, when tested at 1.5 times the normal vacuum downstream of the effluent sampling device.

\begin{tabular}{|c|c|}
\hline Drivers & Discussion and/or Interpretation \\
\hline $\begin{array}{l}\text { DOE/EH-0173T (3h) } \\
5400.1-\mid(8)(a)\end{array}$ & None \\
\hline $\begin{array}{l}\text { DOE/EH-0173T - } \\
3.5 .4\end{array}$ & $\begin{array}{l}\text { Airborne monitoring equipment in place as of } \\
\text { August } 1,1992 \text {, will meet in-leakage testing of } \\
\text { less than } 0.02 \mathrm{cfm} \text { or } 1 \text { percent of normal flow, } \\
\text { whichever is higher, when tested at } 1.5 \text { times } \\
\text { the normal vacuum downstream of the effluent } \\
\text { sampling device. } \\
\text { The criteria contained in this requirement is } \\
\text { based on discussions contained in Leak Test } \\
\text { Method for Air Sampling Systems, WSRC- } \\
\text { TR-93-0585. The requirement, as stated in } \\
\text { DOE/EH-0173T, is based on in-leakage testing } \\
\text { for a grab sampler, not for a continuous sam- } \\
\text { pler. The in-leakage rate-as stated here for a } \\
\text { typical SRS system, which operates at } 3 \text { cfm- } \\
\text { would be 0.015 cfm, which is less than the } \\
\text { DOE/EH-0173T requirement. }\end{array}$ \\
\hline $\begin{array}{l}\text { DOE/EH-0173T (3i) } \\
40 \text { CFR } 61.92\end{array}$ & $\begin{array}{l}\text { The dose standard given in } 40 \text { CFR } 61.92 \text { ap- } \\
\text { plies to all DOE activities at a facility, but the } \\
\text { monitoring criteria in } 40 \text { CFR } 61.93 \text { applies only } \\
\text { to point sources. This requirement will ensure } \\
\text { that data is available to demonstrate com- } \\
\text { pliance with the dose standard of } 40 \text { CFR } \\
61.92 \text {. }\end{array}$ \\
\hline $\begin{array}{l}\text { DOE/EH-0173T (3j) } \\
40 \text { CFR } 61 \text { App. B } \\
40 \text { CFR } 61.93(\mathrm{~b})(2) \\
5400.1-\operatorname{IV}(5)(\mathrm{a})(1) \\
5400.1-\operatorname{IV}(5)(\mathrm{a})(2)\end{array}$ & $\begin{array}{l}\text { The intent of this requirement is to ensure that } \\
\text { the monitoring system is properly designed for } \\
\text { the source being monitored. This criteria is } \\
\text { achieved by meeting the requirements of } 3.3 .1 \text {, } \\
3.3 .2,3.3 .4,3.3 .20 \text {, and } 3.3 .21 \text {. }\end{array}$ \\
\hline
\end{tabular}

3.3.14 Nonpoint sources or multiple-point sources in a limited area (i.e., multiple vented drums) will be identified and assessed for their potential to contribute to public dose and will be considered in designing the site emissions monitoring and environmental surveillance program. Nonpoint sources that contribute 10 percent of the dose to members of the public will be identified, assessed, documented, and verified annually.

3.3.15 Effluent monitoring systems will demonstrate that quantification of airborne emissions is timely, representative, and adequately sensitive. 


\begin{tabular}{|c|c|c|}
\hline Criteria Number and Requirement & Drivers & Discussion and/or Interpretation \\
\hline $\begin{array}{l}\text { 3.3.17 On-line detectors will be required for those emission } \\
\text { points with normal operational emissions that exceed } 2 \text { mrem/ } \\
\text { year. On-line detectors capable of detecting those radionu- } \\
\text { clides that exceed } 10 \text { percent of the emission point's actual } \\
\text { normal operational dose will be used. In addition to any re- } \\
\text { quirement in Section } 3.4 \text {, continuous flow monitoring of both } \\
\text { sample and exhaust flow also will be performed. }\end{array}$ & DOE/EH-0173T (3I) & $\begin{array}{l}\text { This criteria has been modified to account for } \\
\text { SRS activities. The significant potential has } \\
\text { been removed and the criteria applied to any } \\
\text { source with actual emissions greater than } 2 \\
\text { mrem/yr ( } 20 \text { percent of the } 40 \text { CFR } 61.92 \text { stan- } \\
\text { dard). }\end{array}$ \\
\hline $\begin{array}{l}\text { 3.3.18 The design of radioiodine monitors will be such that re- } \\
\text { placement of sorbent and filter paper will not disturb the geom- } \\
\text { etry between the collector and the detector. }\end{array}$ & $\begin{array}{l}\text { 10CFR834.401(f) } \\
\text { DOE/EH-0173T } \\
(3 \mathrm{~m})\end{array}$ & None \\
\hline $\begin{array}{l}\text { 3.3.20 As they apply to airborne effluent monitoring, the gen- } \\
\text { eral quality assurance program requirements identified in } \\
\text { Chapter } 10 \text { ("Quality Assurance") of this document will be fol- } \\
\text { lowed. }\end{array}$ & DOE/EH-0173T (30) & None \\
\hline $\begin{array}{l}\text { 3.3.21 For radiological effluent monitoring, the quality assur- } \\
\text { ance requirements outlined in Method } 114 \text { of } 40 \text { CFR } 61 \text { will be } \\
\text { followed. }\end{array}$ & $\begin{array}{l}40 \text { CFR 61, Appen- } \\
\text { dix B, Method } 114\end{array}$ & None \\
\hline
\end{tabular}




\section{Meteorological Monitoring}

\subsection{General Information and Purpose}

The purpose of this chapter of the Savannah River Site Environmental Monitoring Plan (SRS EM Plan) is to define the meteorological monitoring criteria, regulations, and guideline requirements with which SRS will comply. These criteria and requirements are applicable to meteorological monitoring activities performed in support of SRS environmental monitoring activities. They are not applicable to meteorological monitoring activities utilized exclusively for process monitoring/control.

U.S. Department of Energy (DOE) Order 5400.1 [DOE, 1988], 10 CFR 834 [DOE, 1993], and DOE/ EH-0173T [DOE, 1991] require that a meteorological monitoring program be developed as a specific element of each DOE site's EM Plan. \{5400.1-IV(6.a) and 10 CFR 834.410 (i)\} They also contain general requirements and specific guidance criteria applicable to meteorological monitoring. Other applicable guidance documents include: American Nuclear Society [ANS, 1984] Guide 2.5 and U.S. Environmental Protection Agency (EPA) Guides 600/4-90-003 [EPA, 1990], 450/4-87-007 [EPA, 1987a], and 450/4-87-013 [EPA, 1987b].

A meteorological monitoring program will be established at SRS to

- characterize atmospheric transport and dispersion conditions

- describe meteorological conditions - including precipitation, wind speed, wind direction, and atmospheric stability - that are important to surveillance

- assess consequences of actual routine contaminant releases from existing facilities to demonstrate compliance with applicable regulations and standards

- assess consequences of actual accidental contaminant releases

- assess potential consequences of contaminant releases from new or modified facilities \{5400.1-IV(6.b.1 through 6.b.4) and 10 CFR 834.410 (i.1 through i.3)\}

There are, however, other SRS meteorological data uses that require a longer term database representative of the local climatology. These uses include chronic dosimetric and air quality calculations, engineering analyses, and site environmental characterizations - all contained in safety analysis reports, environmental impact statements, and risk assessments. In addition, the SRS meteorological monitoring program is an integral part of the overall SRS emergency response capability known as the Weather INformation and Display System (WIND System).

\subsection{Definitions}

- Representative Sample - A representative sample is a sample taken to depict the characteristics of a lot or population as accurately and precisely as possible. A representative sample may be random or stratified, depending on the objective of the sampling and the characteristics of the population.

\subsection{Requirements}

Table 4-1, beginning on page 27 , itemizes the meteorological monitoring requirements and associated regulatory and/or guidance "drivers" with which SRS will comply. Where appropriate, specific 


\section{Chapter 4}

interpretation and/or clarifying discussion of a requirement is provided. Unless otherwise noted, all requirements listed are applicable to radiological and nonradiological environmental monitoring programs.

Implementation of these requirements will be documented in the SRS Environmental Monitoring Program (SRS EM Program), WSRC-3Q1-2, Volume 1, Section 1104. Any requirements not fully implemented will be included in the SRS EM Plan Corrective Action Plan, WSRC-ESHEMS-94-0129. 


\begin{tabular}{|c|c|c|}
\hline Criteria Number and Requirement & Drivers & Discussion and/or Interpretation \\
\hline $\begin{array}{l}\text { 4.3.1 SRS will establish a meteorological monitoring pro- } \\
\text { gram that is appropriate for the site's activities and topo- } \\
\text { graphical characteristics and for the distance to critical recep- } \\
\text { tors. }\end{array}$ & $\begin{array}{l}\text { 10 CFR } 834.401 \text { f.6 } \\
\text { DOE/EH-0173T } \\
(4 . \mathrm{a}) \\
5400.1\end{array}$ & None \\
\hline $\begin{array}{l}\text { 4.3.2 The scope of the SRS meteorological monitoring pro- } \\
\text { gram will be based on an evaluation of the regulatory require- } \\
\text { ments, of the meteorological data needed for impact assess- } \\
\text { ments, of the environmental surveillance activities, and of the } \\
\text { emergency response-considering the mathematical proce- } \\
\text { dures, models, and input data requirements necessary to } \\
\text { compute atmospheric transport and diffusion computations } \\
\text { and to perform dose assessments. }\end{array}$ & $\begin{array}{l}\text { DOE/EH-0173T } \\
(4 . b) \\
5400.1\end{array}$ & $\begin{array}{l}\text { A documented evaluation of applicable regulatory } \\
\text { documents for meteorological monitoring was } \\
\text { performed during DOE-SR's } 1993 \text { Comprehen- } \\
\text { sive Compliance Assurance Review (CCAR) of } \\
\text { SRS's Meteorological and Atmospheric Release } \\
\text { Tracking and Monitoring Program. Ref. DOE Re- } \\
\text { port Number 07-01-93-0008. Emergency re- } \\
\text { sponse criteria, which were not included in the } \\
\text { CCAR, will be addressed by the SRS EM } \\
\text { Program. }\end{array}$ \\
\hline $\begin{array}{l}\text { 4.3.3 The program will be documented in the meteorological } \\
\text { monitoring chapter of the SRS Environmental Monitoring Pro- } \\
\text { gram (SRS EM Program). } \\
\text { Ref. WSRC-3Q1-2, Volume1, section } 1104 .\end{array}$ & $\begin{array}{l}10 \text { CFR } 834.401 \text { t.6 } \\
\text { DOE/EH-0173T } \\
(4 . C) \\
5400.1\end{array}$ & None \\
\hline $\begin{array}{l}\text { 4.3.4 Off-site sources of data will be representative of condi- } \\
\text { tions at SRS and will provide statistically valid data consistent } \\
\text { with on-site monitoring requirements. }\end{array}$ & $\begin{array}{l}\text { DOE/EH-0173T } \\
(4 . d) \\
5400.1\end{array}$ & None \\
\hline $\begin{array}{l}\text { 4.3.5 Specific meteorological information requirements at } \\
\text { SRS will be based on the magnitude of potential source } \\
\text { terms, on the nature of potential releases from the facility, on } \\
\text { possible pathways to the atmosphere, and on the distances } \\
\text { from releases points to critical receptors. }\end{array}$ & $\begin{array}{l}\text { DOE/EH-0173T } \\
(4 . e) \\
5400.1\end{array}$ & None \\
\hline
\end{tabular}




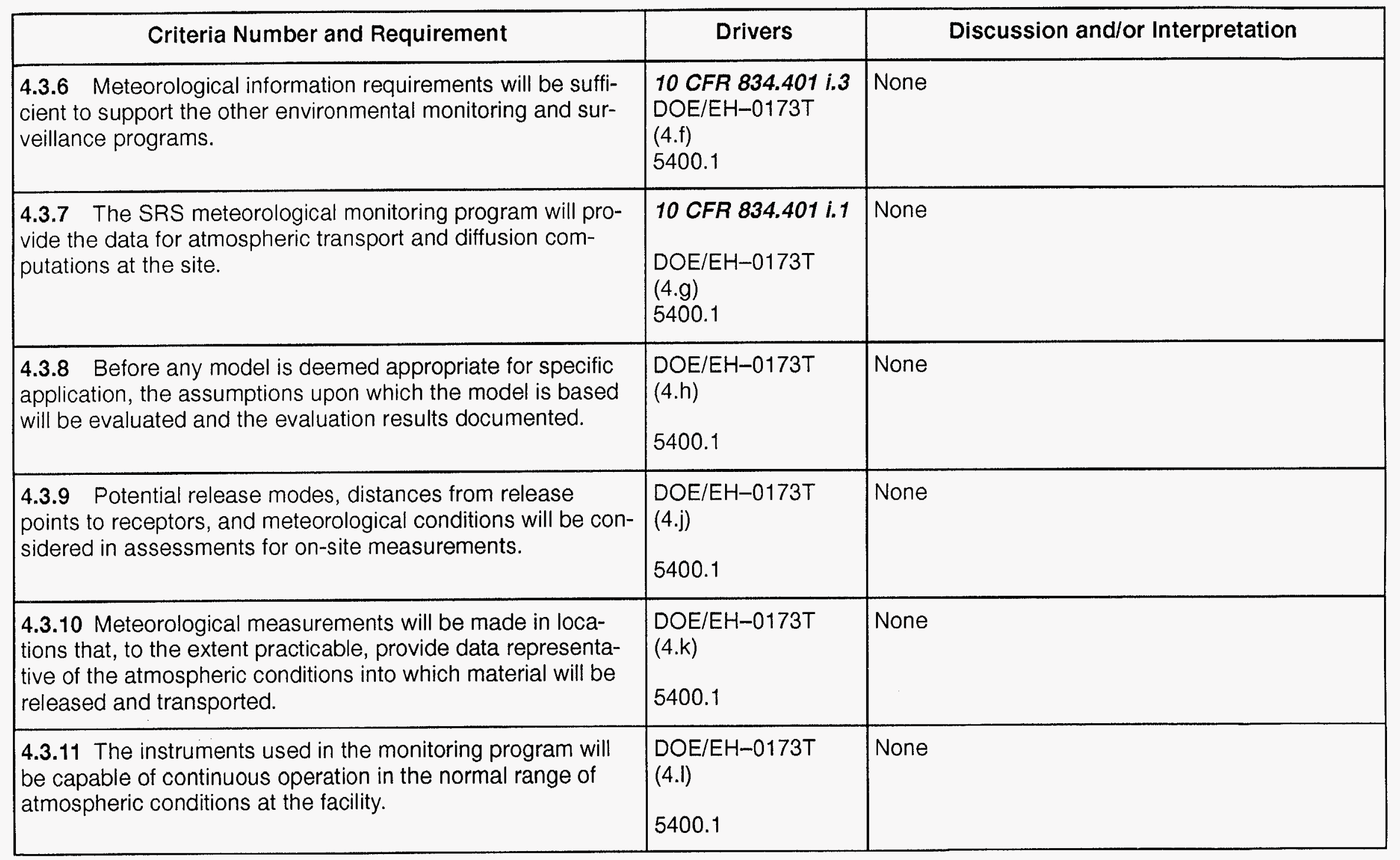




\begin{tabular}{|c|c|c|}
\hline Criteria Number and Requirement & Drivers & Discussion and/or Interpretation \\
\hline $\begin{array}{l}\text { 4.3.13 If instruments are mounted on booms extending to the } \\
\text { side of a tower, the booms will be oriented in directions that } \\
\text { minimize the potential effects of the tower on the measure- } \\
\text { ments. The instruments will be at least two tower diameters } \\
\text { from the tower. }\end{array}$ & $\begin{array}{l}\text { DOE/EH-0173T } \\
(4 . n) \\
5400.1\end{array}$ & None \\
\hline $\begin{array}{l}\text { 4.3.14 The SRS meteorological monitoring program will pro- } \\
\text { vide for routine inspection of the data and for scheduled } \\
\text { maintenance and calibration of the meteorological instrumen- } \\
\text { tation and data-acquisition system at a minimum, based on } \\
\text { the calibration frequency recommendations of the manufac- } \\
\text { turers. }\end{array}$ & $\begin{array}{l}\text { DOE/EH-0173T } \\
(4.0) \\
5400.1\end{array}$ & None \\
\hline $\begin{array}{l}\text { 4.3.16 The instrument system will provide data recovery of at } \\
\text { least } 90 \text { percent on an annual basis for wind direction, for } \\
\text { wind speed, for those parameters necessary to classify atmo- } \\
\text { spheric stability, and for other meteorological elements re- } \\
\text { quired for dose assessment. }\end{array}$ & $\begin{array}{l}10 \text { CFR } 834.401 \text { i.2 } \\
\text { DOE/EH-0173T } \\
\text { (4.q) } \\
5400.1\end{array}$ & None \\
\hline
\end{tabular}




\begin{tabular}{|l|l|l|}
\hline \multicolumn{1}{|c|}{ Criteria Number and Requirement } & \multicolumn{1}{|c|}{ Drivers } & \multicolumn{1}{|c|}{ Discussion and/or Interpretation } \\
\hline $\begin{array}{l}\text { 4.3.17 The topographic setting of a facility and the distances } \\
\text { from the facility to points of public access will be considered } \\
\text { when evaluating the need for supplementary instrumentation. }\end{array}$ & $\begin{array}{l}\text { DOE/EH-0173T } \\
(4 . r) \\
5400.1\end{array}$ & None \\
\hline $\begin{array}{l}\text { 4.3.18 If meteorological measurements at a single location } \\
\text { cannot adequately represent atmospheric conditions for } \\
\text { transport and diffusion computations, supplementary mea- } \\
\text { surements will be made. }\end{array}$ & $\begin{array}{l}\text { DOE/EH-0173T } \\
(4.5)\end{array}$ & None \\
\hline $\begin{array}{l}\text { 4.3.19 A sitewide meteorological monitoring program will be } \\
\text { established at each multifacility site to provide a comprehen- } \\
\text { sive database that can be used for all facilities located within } \\
\text { the site. }\end{array}$ & $\begin{array}{l}\text { DOE/EH-0173T } \\
(4 . t) \\
5400.1\end{array}$ & None \\
\hline $\begin{array}{l}\text { 4.3.20 As they apply to meteorological monitoring, the gener- } \\
\text { al quality assurance program requirements identified in Chap- } \\
\text { ter 10 (“Quality Assurance") of this document will be followed. }\end{array}$ & $\begin{array}{l}\text { DOE/EH-0173T } \\
(4 . \mathrm{U})\end{array}$ & None \\
\hline
\end{tabular}

Note: DOE/EH-0173T requirement $4 . i$ is not applicable to SRS. 


\section{Environmental Surveillance}

\subsection{General Information and Purpose}

The purpose of this chapter of the Savannah River Site Environmental Monitoring Plan (SRS EM Plan) is to define the environmental surveillance criteria, regulations, and guideline requirements with which SRS will comply.

The SRS environmental surveillance program will consist of radiological and nonradiological surveillance of surface waters, groundwater, drinking water, rainwater, atmosphere, sediment, soil, biota, and foodstuffs. The radiological program is driven by 10 CFR 834 [DOE, 1993], U.S. Department of Energy (DOE) Orders 5400.1 [DOE, 1988] and 5400.5 [DOE, 1990], DOE/EH-0173T [DOE, 1991], and the U.S. Environmental Protection Agency's (EPA) Resource Conservation and Recovery Act and Comprehensive Environmental Response, Compensation, and Liability Act (RCRA/CERCLA) regulations. The nonradiological program will be used to demonstrate compliance with the following federal and state regulations:

- DOE Order 5400.1

- RCRA

- CERCLA

- 40 CFR 264 [EPA, 1980a]

- 40 CFR 265 [EPA, 1980b]

- EPA 570/9-76-003 ( $\mathrm{Hg}$ in fish) [EPA,1977]

- Clean Water Act

- National Pollutant Discharge Elimination System (NPDES)

- South Carolina Water Quality Standards R61-79, 61-68, 61-69, 61-9, 61-58

- Wood Stork Program

- Federal Insecticide, Fungicide, and Rodenticide Act (FIFRA) (pesticides in sediment)

As required by 10 CFR 834 and DOE Order 5400.1, an environmental surveillance program will be developed at SRS to

- verify compliance with applicable environmental standards and public exposure limits

- establish background levels of contaminants in the environment

- utilize monitoring stations on the basis of the type of emission, meteorology, climatology, topography, geography, population distribution, land use, and other relevant considerations

- determine the location and magnitude of concentrations of pollutants from SRS activities

- verify the effectiveness of effluent treatment and controls in reducing contaminant emissions

- evaluate the effects on the public and the environment of contaminants from SRS activities

- characterize and define trends in the physical, chemical, and biological condition of environmental media 
- collect and analyze samples in a manner and frequency sufficient to characterize the emissions, and their effects, from SRS activities

- verify whether any unexpected or undetected releases occur \{5400.1-IV(5.b.1) and 10 CFR 834.410 (h.1 through h.6)\}

\subsection{Definitions}

- Control Locations - Control locations are sampling locations assumed to contain no significant amount of the analyte of interest, but whose measurements are compared with those of other test sites to determine to what extent that analyte is present.

- Critical Pathway - A critical pathway is the specific route of transfer of contaminants from one environmental component to another that results in the greatest fraction of an applicable dose limit to a population group or to an individual's whole body, organ, or tissue.

- Environmental Medium - Environmental medium is a discrete portion of the total environment, animate or inanimate, that may be sampled or measured directly.

- Environmental Surveillance - Environmental surveillance is the collection and analysis of samples of air, water, soil, foodstuffs, biota, and other media and the measurement of external radiation for purposes of demonstrating compliance with applicable standards, assessing exposures to members of the public, and assessing effects, if any, on the local environment.

- Representative Sample - A representative sample is a sample taken to depict the characteristics of a lot or population as accurately and precisely as possible. It may be a random or stratified sample, depending on the objective of the sampling.

\subsection{Requirements}

Table 5-1, beginning on page 33, itemizes the environmental surveillance requirements and the associated regulatory and/or guidance "drivers" with which SRS will comply. Where appropriate, specific interpretation and/or clarifying discussion of a requirement is provided. Unless otherwise noted, all requirements listed are applicable to radiological and nonradiological environmental monitoring programs.

Implementation of these requirements will be documented in the SRS Environmental Monitoring Program (SRS EM Program), WSRC-3Q1-2, Volume 1, Section 1105. Any requirements not fully implemented will be included in the SRS EM Plan Corrective Action Plan, WSRC-ESHEMS-94-0129. 
Table 5-1 Requirements (5.3)

\begin{tabular}{|c|c|c|}
\hline Criteria Number and Requirement & Drivers & Discussion and/or Interpretation \\
\hline $\begin{array}{l}\text { 5.3.1 An evaluation will be conducted and used as the basis } \\
\text { for establishing an environmental surveillance program for } \\
\text { SRS. The purpose of the surveillance program is to characterize } \\
\text { the conditions of the off-site environs and, if appropriate, to esti- } \\
\text { mate public doses related to these conditions, confirm predic- } \\
\text { tions of public doses based on effluent monitoring data, and pro- } \\
\text { vide compliance data for all applicable regulations. The results } \\
\text { of this evaluation will be documented in the SRS Environmental } \\
\text { Monitoring Program (SRS EM Program). } \\
\text { Ref. WSRC-3Q1-2, Volume1, section } 1105 \text {. }\end{array}$ & $\begin{array}{l}\text { DOE/EH-0173T } \\
\text { (5.a) } \\
5400.1 \\
\text { Task team } \\
\text { recommendation for } \\
\text { nonradiological } \\
\text { surveillances }\end{array}$ & None \\
\hline $\begin{array}{l}\text { 5.3.2 The environmental surveillance program for DOE-con- } \\
\text { trolled sites will be conducted in accordance with the require- } \\
\text { ments of } 10 \text { CFR } 834, \text { DOE } 5400.1 \text {, and DOE } 5400.5 \text {. }\end{array}$ & $\begin{array}{l}10 \text { CFR } 834.3(3) \\
10 \text { CFR } 834.401 \mathrm{~h} \\
\text { DOE/EH-173T (5.b) } \\
5400.1 \\
5400.5\end{array}$ & None \\
\hline $\begin{array}{l}\text { 5.3.3 The criteria for environmental surveillance programs } \\
\text { listed in Chapter } 5 \text { (of DOE/EH-173T) will be used for establish- } \\
\text { ing the environmental surveillance program for SRS. Additional } \\
\text { site-specific criteria will be documented in the SRS EM Pro- } \\
\text { gram. }\end{array}$ & DOE/EH-173T (5.c) & None \\
\hline $\begin{array}{l}\text { 5.3.4 The need for environmental sampling and analysis will } \\
\text { be evaluated by exposure pathway analysis for each site efflu- } \\
\text { ent or emission (liquid or airborne). This analysis-with ap- } \\
\text { propriate data, references, and site-specific assumptions, along } \\
\text { with site-specific criteria for selection of samples, measure- } \\
\text { ments, instrumentation, equipment, and sampling or measure- } \\
\text { ment locations-will be documented in the SRS EM Program. }\end{array}$ & $\begin{array}{l}10 \text { CFR } 834.401 \text { f.3 } \\
10 \text { CFR } 834.401 \text { h.4 } \\
10 \text { CFR } 834.401 \text { h.5 } \\
\text { DOE/EH-173T (5.d) }\end{array}$ & None \\
\hline
\end{tabular}




\begin{tabular}{|c|c|c|}
\hline Criteria Number and Requirement & Drivers & Discussion and/or Interpretation \\
\hline $\begin{array}{l}\text { 5.3.5 A critical pathway analysis (contaminant/media) will be } \\
\text { performed, documented, and referenced in the EM Program } \\
\text { and in the annual SRS Environmental Report. }\end{array}$ & DOE/EH-173T (5.e) & None \\
\hline $\begin{array}{l}\text { 5.3.6 If the projected dose equivalent from inhalation of partic- } \\
\text { ulates exceeds the criteria of Chapter } 5 \text { of DOE/EH-0173T, par- } \\
\text { ticle-size analysis of the emission will be conducted at least } \\
\text { annually. }\end{array}$ & DOE/EH-173T (5.f) & $\begin{array}{l}\text { If required by pathway analysis (see item } 5.3 .1 \text { ), im- } \\
\text { plementation of this criteria will be described in the } \\
\text { EM Program. } \\
\text { This requirement is only applicable for radiological } \\
\text { programs. }\end{array}$ \\
\hline $\begin{array}{l}\text { 5.3.7 Further provisions will be made, as appropriate, for the } \\
\text { detection and quantification of unplanned releases to the envi- } \\
\text { ronment or of radioactive materials, including contaminants that } \\
\text { may be transported by stormwater runoff, flooding, or resuspen- } \\
\text { sion of ground-deposited material. }\end{array}$ & $\begin{array}{l}10 \text { CFR } 834.401 \text { h.6 } \\
\text { DOE/EH-173T (5.g) } \\
5400.1\end{array}$ & None \\
\hline $\begin{array}{l}\text { 5.3.9 Calibration of dosimeters and exposure-rate instru- } \\
\text { ments will be based on traceability to NIST standards. }\end{array}$ & DOE/EH-173T (5.i) & $\begin{array}{l}\text { This requirement is only applicable for radiological } \\
\text { programs. }\end{array}$ \\
\hline
\end{tabular}




\begin{tabular}{|c|c|c|}
\hline Criteria Number and Requirement & Drivers & Discussion and/or Interpretation \\
\hline $\begin{array}{l}\text { 5.3.10 Gross radioactivity analyses will be used only as trend } \\
\text { indicators, unless documented supporting analyses provide a } \\
\text { reliable relationship to specific radionuclide concentrations or } \\
\text { doses. }\end{array}$ & DOE/EH-173T (5.j) & $\begin{array}{l}\text { This requirement is only applicable for radiological } \\
\text { programs. }\end{array}$ \\
\hline $\begin{array}{l}\text { 5.3.11 The overall accuracy ( } \pm \text { percent accuracy) will be esti- } \\
\text { mated, and the approximate environmental detection limit at a } \\
\text { specified percent confidence level for environmental measure- } \\
\text { ments of beta-gammas, alphas, and neutrons, as appropriate, } \\
\text { will be determined and documented. }\end{array}$ & DOE/EH-173T (5.k) & $\begin{array}{l}\text { This requirement is only applicable for radiological } \\
\text { programs. }\end{array}$ \\
\hline $\begin{array}{l}\text { 5.3.12 Sample preservation methods will be consistent with the } \\
\text { analytical procedures used. }\end{array}$ & DOE/EH-173T (5.I) & None \\
\hline $\begin{array}{l}\text { 5.3.13 All environmental surveillance techniques will be de- } \\
\text { signed to take a representative sample or measurement of the } \\
\text { important contaminant exposure pathway media. }\end{array}$ & $\begin{array}{l}10 \text { CFR } 834.401 \text { h.2 } \\
\text { DOE/EH-173T } \\
(5 . \mathrm{m})\end{array}$ & None \\
\hline $\begin{array}{l}\text { 5.3.14 Sampling or measurement frequencies for each signifi- } \\
\text { cant radionuclide or environmental medium combination (e.g., } \\
\text { those contributing } 10 \text { percent or more to off-site doses greater } \\
\text { than } 0.1 \text { mrem effective dose equivalent from emissions in a } \\
\text { year) will take into account the half-life of the radionuclides to be } \\
\text { measured and will be documented in the site EM Program. }\end{array}$ & DOE/EH-173T (5.n) & $\begin{array}{l}\text { This requirement is only applicable for radiological } \\
\text { programs. }\end{array}$ \\
\hline $\begin{array}{l}\text { 5.3.15 "Background" or "control" location measurements will be } \\
\text { made for every significant radionuclide and pathway combina- } \\
\text { tion (e.g., those contributing } 10 \text { percent or more to off-site doses } \\
\text { greater than } 0.1 \text { mrem effective dose equivalent from emissions } \\
\text { in a year) for which environmental measurements are used in } \\
\text { the dose calculations. }\end{array}$ & $\begin{array}{l}10 \text { CFR } 834.401 h .1 \\
D O E / E H-173 T(5.0)\end{array} \mid$ & $\begin{array}{l}\text { This requirement is only applicable for radiological } \\
\text { programs. }\end{array}$ \\
\hline
\end{tabular}




\begin{tabular}{|c|c|c|}
\hline Criteria Number and Requirement & Drivers & Discussion and/or Interpretation \\
\hline $\begin{array}{l}\text { 5.3.16 An annual review of the contaminant composition of ef- } \\
\text { fluents or emissions will be made and compared with those used } \\
\text { to establish the site EM Program. Any deviations from routine } \\
\text { environmental surveillance requirements, including sampling or } \\
\text { measurement station placement, will be documented in the } \\
\text { SRS EM Program. }\end{array}$ & DOE/EH-173T (5.p) & None \\
\hline $\begin{array}{l}\text { 5.3.18 State and local game officials will be consulted when se- } \\
\text { lecting appropriate protected species to sample. }\end{array}$ & DOE/EH-173T (5.r) & None \\
\hline $\begin{array}{l}\text { 5.3.20 Any changes in the site-specific or generic factor will be } \\
\text { noted in the SRS EM Program, and the retired or replaced val- } \\
\text { ues will be preserved for historical purposes. }\end{array}$ & DOE/EH-173T (5.t) & None \\
\hline $\begin{array}{l}\text { 5.3.21 When neutron monitoring is required, the method of } \\
\text { measurement will be based on the anticipated flux and energy } \\
\text { spectrum. }\end{array}$ & DOE/EH-173T (5.u) & $\begin{array}{l}\text { If required by pathway analysis (see item } 5.1 \text { ), neu- } \\
\text { tron monitoring requirements will be described in } \\
\text { the EM Program. } \\
\text { This requirement is only applicable for radiological } \\
\text { programs. }\end{array}$ \\
\hline
\end{tabular}




\begin{tabular}{|l|l|l|}
\hline \multicolumn{1}{|c|}{ Criteria Number and Requirement } & \multicolumn{1}{|c|}{ Drivers } & \multicolumn{1}{c|}{ Discussion and/or Interpretation } \\
\hline $\begin{array}{l}\text { 5.3.22 The sample exchange frequency for nonparticulate } \\
\text { sampling will be determined on a site-specific basis and docu- } \\
\text { mented in the environmental surveillance files. }\end{array}$ & DOE/EH-173T (5.v) & None \\
\hline $\begin{array}{l}\text { 5.3.23 The analytical procedure to be used will be considered } \\
\text { when choosing a method for preserving milk samples. }\end{array}$ & DOE/EH-173T (5.w) & None \\
\hline $\begin{array}{l}\text { 5.3.24 As they apply to environmental surveillance activities, } \\
\text { the general quality assurance program provisions of Chapter 10 } \\
\text { ("Quality Assurance") of this document will be followed. }\end{array}$ & DOE/EH-173T (5.x) & None \\
\hline
\end{tabular}




\section{Laboratory Procedures}

\subsection{General Information and Purpose}

The purpose of this chapter of the Savannah River Site Environmental Monitoring Plan (SRS EM Plan) is to define the environmental monitoring laboratory procedures criteria, regulations, and guideline requirements with which SRS will comply.

The following regulations contain the laboratory procedure requirements applicable to the site's environmental monitoring programs:

- 10 CFR 834 [DOE, 1993]

- DOE/EH-173T [DOE, 1991]

- U.S. Department of Energy (DOE) Order 5400.1 [DOE, 1988]

- 40 CFR 60, Appendix A [EPA, 1973a]

- 40 CFR 61, Appendix B, Method 114 [EPA, 1989]

- National Pollutant Discharge Elimination System (NPDES)

- 40 CFR 136 [EPA, 1973b]

- 40 CFR 264 [EPA, 1980a]

- 40 CFR 265 [EPA, 1980b]

- Resource Conservation and Recovery Act (RCRA)

- Comprehensive Environmental Response, Compensation, and Liability Act (CERCLA)

Written analytical procedures will be established and implemented to ensure the quality of the environmental and effluent data produced at SRS. Where possible, standard analyses will be utilized to analyze samples. \{5400.1-IV (2.c) and 10 CFR 834.410 (f.4)\}

For radiological monitoring, the radioanalytical procedures used will be consistent with standards or guidelines such as those contained or referenced in

- HASL-300, "U.S. Department of Energy Environmental Measurements Laboratory Procedures Manual" (revised annually) [HASL-300]

- 40 CFR 61, Appendix B, Method 114"

- EPA-600/4-80-032 [EPA, 1980c]

- DOE/EH-0173T

- NCRP Report No. 58 [NCRP, 1978]

U.S. Environmental Protection Agency (EPA)-approved or regulatory accepted methods will be used for analysis of nonradiological parameters. These methods typically are found in "Methods of Chemical Analysis of Water and Wastes," EPA-600/4-79-020 [EPA, 1979]; "Methods for Organic Chemical Analysis of Municipal and Industrial Wastewater," EPA-600/4-82-057 [EPA, 1982]; and "Standard Methods for the Examination of Water and Wastewater," 16th Edition [APHA, 1985]. 


\subsection{Definitions}

- Calibration - Calibration is the adjustment of a system and the determination of the system's accuracy using known sources and instrument measurements. Adjustments must be conducted using written procedures and calibration standards traceable to the National Institute of Standards and Technology (NIST).

- Check Source - A check source is used to confirm the continuing satisfactory operation of an instrument. A check source in not necessarily calibrated.

\subsection{Requirements}

Table 6-1, beginning on page 41 , itemizes the laboratory procedure requirements and associated regulatory and/or guidance "drivers" with which SRS will comply. Where appropriate, specific interpretation and/or clarifying discussion of a requirement is provided. Unless otherwise noted, all requirements listed are applicable to radiological and nonradiological environmental monitoring programs.

Implementation of these requirements will be documented in the SRS Environmental Monitoring Program (SRS EM Program), WSRC-3Q1-2, Volume 1, Section 1106. Any requirements not fully implemented will be included in the SRS EM Plan Corrective Action Plan, WSRC-ESHEMS-94-0129. 
Table 6-1 Requirements (6.3)

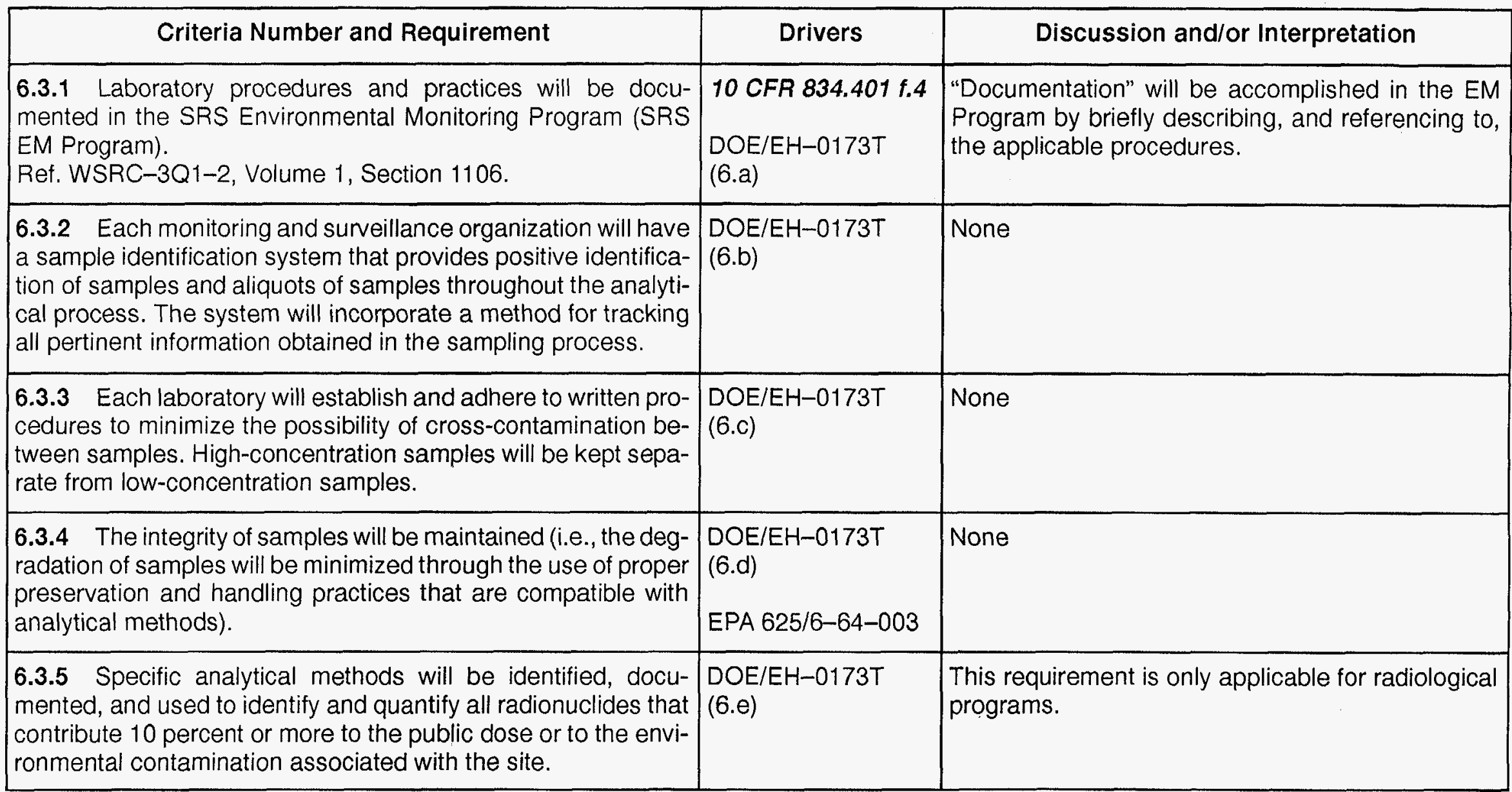




\begin{tabular}{|c|c|c|}
\hline Criteria Number and Requirement & Drivers & Discussion and/or Interpretation \\
\hline $\begin{array}{l}\text { 6.3.6 Standard analytical methods will be used, when avail- } \\
\text { able, for radiological and nonradiological analyses. } \\
\text { Any modification of standard methods will be documented in the } \\
\text { SRS EM Program. }\end{array}$ & $\begin{array}{l}\text { DOE/EH-0173T } \\
(6 . f) \\
5400.1\end{array}$ & $\begin{array}{l}\text { Basis and justification of existing analytical procedures will be docu- } \\
\text { mented in the SRS EM Program. Any modification to standard methods } \\
\text { also will be documented. A separate technical report may be used as } \\
\text { needed. }\end{array}$ \\
\hline $\begin{array}{l}\text { 6.3.7 Methods, requirements, and necessary documentation } \\
\text { will be specified in analytical contracts. }\end{array}$ & $\begin{array}{l}\text { DOE/EH-0173T } \\
(6 . g)\end{array}$ & None \\
\hline $\begin{array}{l}\text { 6.3.8 All sites that release or could release gamma-emitting } \\
\text { radionuclides will have the capability (either in-house or outside) } \\
\text { of having samples (routine, special, or emergency) analyzed by } \\
\text { gamma-ray spectroscopy systems. }\end{array}$ & $\begin{array}{l}\text { DOE/EH-0173T } \\
(6 . h)\end{array}$ & $\begin{array}{l}\text { This requirement is only applicable for radiological } \\
\text { programs. }\end{array}$ \\
\hline $\begin{array}{l}\text { 6.3.9 Analytical equipment will be calibrated using, at a mini- } \\
\text { mum, the manufacturers' calibration frequency recommenda- } \\
\text { tions to obtain accurate results. }\end{array}$ & $\begin{array}{l}\text { DOE/EH-0173T } \\
(6 . i)\end{array}$ & None \\
\hline $\begin{array}{l}\text { 6.3.10 Check sources will be counted periodically on all count- } \\
\text { ers to verify that the counters are giving accurate results. }\end{array}$ & $\begin{array}{l}\text { DOE/EH-0173T } \\
(6 . j)\end{array}$ & $\begin{array}{l}\text { This requirement is only applicable for radiological } \\
\text { programs. }\end{array}$ \\
\hline $\begin{array}{l}\text { 6.3.11 Samples that are sent off site for analysis or for } \\
\text { laboratory intercomparison will be monitored for contamination } \\
\text { and/or radiation levels and packaged in a manner that meets ap- } \\
\text { plicable transportation regulations and requirements. }\end{array}$ & $\begin{array}{l}\text { DOE/EH-0173T } \\
(6 . \mathrm{k})\end{array}$ & None \\
\hline $\begin{array}{l}\text { 6.3.12 As they apply to laboratory procedures, the general } \\
\text { quality } \\
\text { assurance program provisions of Chapter } 10 \text { ("Quality Assur- } \\
\text { ance") of this document will be followed. }\end{array}$ & $\begin{array}{l}\text { DOE/EH-0.173T } \\
(6 . I)\end{array}$ & None \\
\hline
\end{tabular}




\section{Data Analysis}

\subsection{General Information and Purpose}

The purpose of this chapter of the Savannah River Site Environmental Monitoring Plan (SRS EM Plan) is to define the environmental and effluent data analysis criteria, regulations, and guideline requirements with which SRS will comply.

The following regulations and guidances contain the environmental data analysis requirements applicable to SRS's environmental monitoring program:

- U.S. Department of Energy (DOE) Order 5400.1 [DOE, 1988]

- DOE Order 5400.5 [DOE, 1990]

- 10 CFR 834 [DOE, 1993]

- 40 CFr 61 [EPA, 1989]

- 40 CFR 136 [EPA, 1973b]

- DOE/EH-173T [DOE, 1991]

- U.S.C. 300f (R61-69) (water classification standards for South Carolina)

- DOE/EP-0023 (guidance document) [DOE, 1981]

- U.S. Environmental Protection Agency (EPA) 520/1-80-012 [EPA, 1980d]

- Resource Conservation and Recovery Act (RCRA)

- Comprehensive Environmental Response, Compensation, and Liability Act (CERCLA)

Analytical data generated as part of the SRS environmental surveillance and effluent monitoring programs will be used in assessing the state of the surrounding environment, the effects (if any) of site operations on the surrounding area, and the impact of operations on the health and safety of the general public. The environmental monitoring activities performed at SRS will produce estimated levels of selected analytes at sample and control locations. These measurements, along with their accuracy and precision, will support the following types of data analyses:

- Temporal analyses that will identify changes or inconsistencies in sample results

- Spatial analyses that will aid in assessing any impact the site may have on the environment

- Comparative analyses that will indicate the status of compliance with applicable regulations, operational limits, and other guidelines

After validation, analytical results will be made available to be reported in site or public documents, including the annual SRS Environmental Report.

\subsection{Definitions}

- Analyte - An analyte is a constituent or parameter being analyzed.

- Continuous monitoring - Continuous monitoring is the real-time measurement of liquid, gaseous, and/or airborne effluents and contaminants using in situ measurement systems. 
- Control locations - Control locations are sampling locations assumed to contain no significant amount of the analyte of interest, but whose measurements are compared with those of other test sites to determine to what extent that analyte is present.

- Outlier - An outlier is an extreme value, in a data set, so far removed from the other values with which it it associated that the chance probability of its being a valid member of the group is very small. Such a questionable value may be eliminated from the group on the basis of further statistical investigations of the data set.

\subsection{Requirements}

Table 7-1, beginning on page 45 , itemizes the data analysis requirements and associated regulatory and/or guidance "drivers" with which SRS will comply. Where appropriate, specific interpretation and/or clarifying discussion of a requirement is provided. Unless otherwise noted, all requirements listed are applicable to radiological and nonradiological environmental monitoring programs.

Implementation of these requirements will be documented in the SRS Environmental Monitoring Program (SRS EM Program), WSRC-3Q1-2, Volume 1, Section 1107. Any requirements not fully implemented will be included in the SRS EM Plan Corrective Action Plan, WSRC-ESHEMS-94-0129. 
Table 7-1 Requirements (7.3)

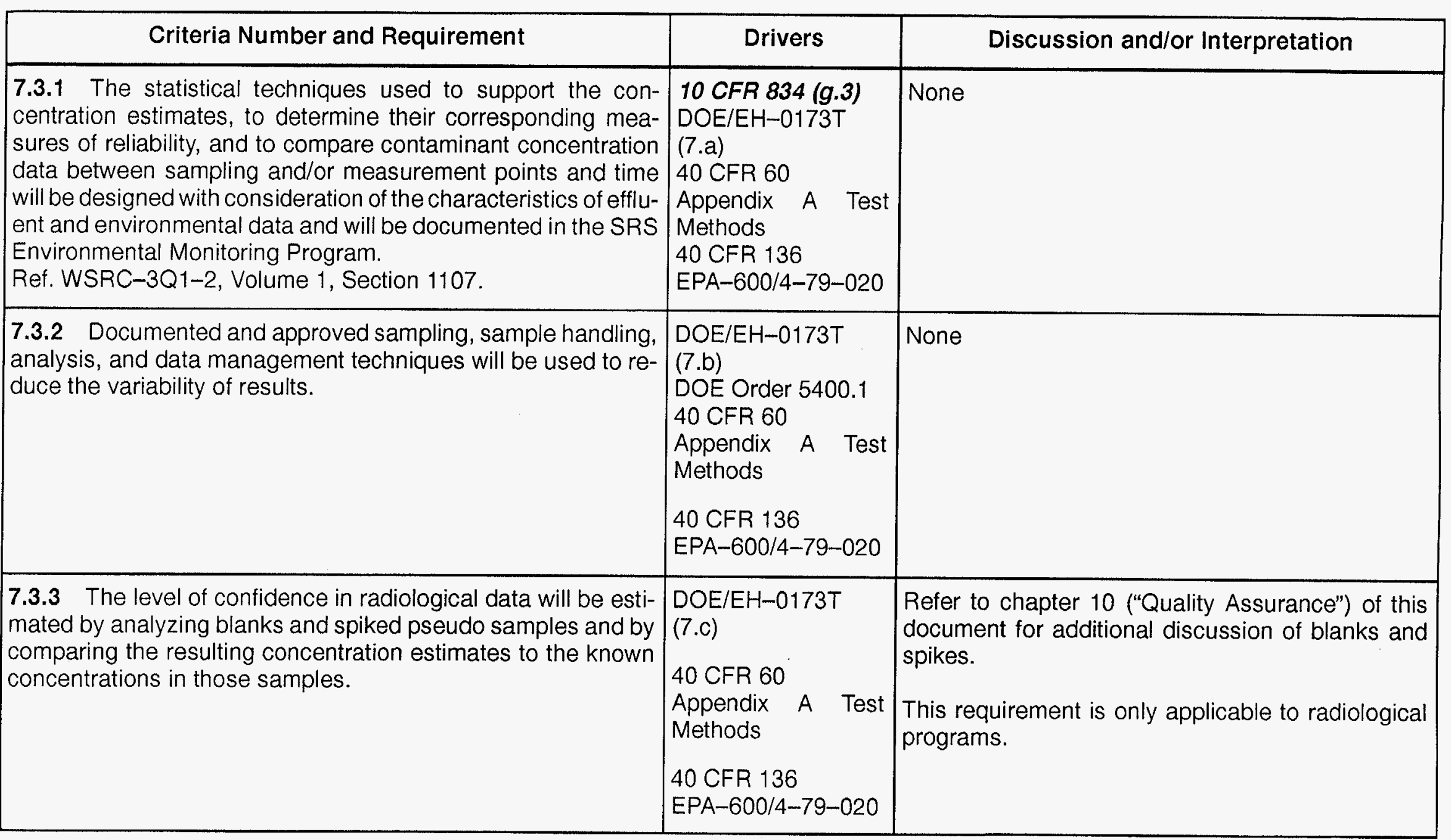




\begin{tabular}{|c|c|c|}
\hline Criteria Number and Requirement & Drivers & Discussion and/or Interpretation \\
\hline $\begin{array}{l}\text { 7.3.4 The precision of radionuclide analytical results will be re- } \\
\text { ported as a range, a variance, a standard deviation, a standard } \\
\text { error, and/or a confidence interval. }\end{array}$ & $\begin{array}{l}\text { DOE/EH-0173T } \\
\text { (7.d) } \\
\text { 40 CFR } 60 \\
\text { Appendix A Test } \\
\text { Methods } \\
\text { 40 CFR 136 } \\
\text { EPA-600/4-79-020 }\end{array}$ & None \\
\hline $\begin{array}{l}\text { 7.3.5 Data will be examined and entered into the data base } \\
\text { promptly after analysis. }\end{array}$ & $\begin{array}{l}\text { DOE/EH-0173T } \\
(7 . e)\end{array}$ & None \\
\hline $\begin{array}{l}\text { 7.3.6 Outliers will be excluded from the data only after inves- } \\
\text { tigation confirms that an error has been made in the sample } \\
\text { collection, preparation, measurement, or data analysis process. } \\
\text { As each data point is collected, it will be compared to previous } \\
\text { data because such a comparison can help identify unusual } \\
\text { measurements that require investigation or further statistical } \\
\text { evaluation. }\end{array}$ & $\begin{array}{l}\text { DOE/EH-0173T } \\
(7 . f) \\
40 \text { CFR } 60 \\
\text { Appendix A Test } \\
\text { Methods } \\
\text { 40 CFR 136 } \\
\text { EPA-600/4-79-020 }\end{array}$ & None \\
\hline $\begin{array}{l}\text { 7.3.7 As they apply to data analysis and statistical treatment } \\
\text { activities, the general quality assurance program provisions of } \\
\text { chapter } 10 \text { ("Quality Assurance") of this document will be fol- } \\
\text { lowed. }\end{array}$ & $\begin{array}{l}\text { DOE/EH-0173T } \\
(7 . \mathrm{g})\end{array}$ & None \\
\hline $\begin{array}{l}\text { 7.3.8 For non-EMS-generated data, the data analysis and } \\
\text { statistical techniques will be consistent with EMS data analysis. }\end{array}$ & $\begin{array}{l}\text { Task team } \\
\text { recommendation }\end{array}$ & None \\
\hline
\end{tabular}




\section{Dose Assessments}

\subsection{General Information and Purpose}

The purpose of this chapter of the Savannah River Site Environmental Monitoring Plan (SRS EM Plan) is to define the radiological dose assessment and nonradiological exposure assessment criteria, regulations, and guideline requirements with which SRS will comply. These criteria and requirements are applicable to dose and exposure assessments performed in support of the SRS Environmental Monitoring Program (SRS EM Program), WSRC-3Q1-2, Volume 1, Section 1108. They are not applicable to dose and exposure assessments utilized exclusively for process monitoring/control.

The following rules, regulations, and guidances contain the radiological dose assessment requirements applicable to SRS:

- U.S. Department of Energy (DOE) Order 5400.1 [DOE, 1988]

- DOE Order 5400.5 [DOE, 1990]

- 10 CFR 834 [DOE, 1993]

- DOE/EH-0173T [DOE, 1991]

- 40 CFR 61 [EPA, 1989]

- 40 CFR 141 [EPA, 1975]

The following rules, regulations, and guidances contain the nonradiological dose assessment requirements applicable to SRS:

- Clean Air Act

- South Carolina Department of Health and Environmental Control (SCDHEC) Regulation 62.5, Standard No. 2. [SCDHEC, 1976]

- SCDHEC Air Quality Modeling Guidelines [SCDHEC, 1992]

Radiological dose assessments and nonradiological exposure assessments will be performed at SRS using standard U.S. Environmental Protection Agency (EPA) or DOE dose conversion factors or analytical models prescribed in statutes or regulations applicable to DOE sites; these assessments will be utilized to

- demonstrate regulatory compliance of routine operations

- determine the effects of unplanned releases

- support the reporting requirements of the annual SRS Environmental Report

- support the SRS Environmental ALARA Program \{5400.1-IV(7.b) and 5400.5-I(10.a) and 10 CFR 834.10 (a.1)\}

Assessments performed for other purposes, such as evaluation of remedial action plans, will conform with the requirements of the SRS EM Plan.

\subsubsection{Radiological Dose Assessments}

DOE Order 5400.5 and 10 CFR 834 set annual radiological dose limits for exposure to the public through various pathways from DOE operations. Dose limits have been established for the airborne 
pathway (10 mrem per year), public drinking water pathway (4 mrem per year), and all pathways combined (100 mrem per year). $\{5400.5-$ II and 10 CFR 834.101, 834.102 and 834.103\}

To demonstrate compliance with these dose standards, human doses will be assessed at SRS for all significant pathways of radiological exposure (i.e., plume, terrestrial, meat, milk, vegetation, inhalation, drinking water, aquatic foods, river recreation, and farm irrigation) for each dose receptor (individual or collective group). Appropriate pathway doses for receptors will be summed to provide total doses for atmospheric and liquid effluents. Doses calculated for radioactive atmospheric and liquid effluents will include the following:

Atmospheric

- Dose to maximally exposed individual

- Collective Dose to $80-\mathrm{km}$ (50-mile) population

\section{Liquid}

- Dose to maximally exposed individual

- Collective dose to $80-\mathrm{km}$ (50-mile) population

- Dose to maximally exposed individual customer of downstream water treatment plants

- Collective dose to customers of downstream water treatment plants

- Potential individual and collective doses from irrigation with river water

In addition to the above radiological dose evaluations, doses from radioactive atmospheric releases for the maximally exposed off-site individual will be calculated with EPA-prescribed methods to demonstrate compliance with the 10 mrem per year dose standard of 40 CFR 61 .

To protect native aquatic animal organisms, DOE Order 5400.5 and 10 CFR 834 establish a radiological dose standard of $1 \mathrm{rad}$ per day from exposure to radioactive liquid effluents. To demonstrate compliance with this dose standard, dose to aquatic organisms in SRS surface streams will be assessed at SRS using DOE-recommended dose models. \{5400.5-I (3.a.3) and 10 CFR 834.101, 834.102 and 834.103\}

\subsubsection{Nonradiological Exposure Assessments}

Nonradiological exposure assessments from nonradioactive atmospheric releases will be calculated with EPA-prescribed modeling methods to demonstrate compliance with SCDHEC Regulation 62.5, Standard No. 2.

\subsection{Definitions}

- Dose - The generic term "dose" refers to the committed effective dose equivalent (50-year committed dose) from internal deposition of radionuclides and to the effective dose equivalent attributable to penetrating radiation from sources external to the body.

- Committed dose equivalent - The committed dose equivalent is the calculated total dose equivalent to a tissue or organ over a 50-year period after known intake of a radionuclide into the body. Contributions from external dose are not included. Committed dose equivalent is expressed in units of rem (or sievert).

- Effective dose equivalent - The effective dose equivalent is the sum of the dose equivalents received by all organs or tissues of the body after each one has been multiplied by an appro- 
priate weighting factor. The effective dose equivalent includes the committed effective dose equivalent from internal deposition of radionuclides and the effective dose equivalent attributable to sources external to the body.

- Collective dose equivalent - The collective dose equivalent is the sum of the dose equivalents of all individuals in a specified population, frequently considered to be that within 80 $\mathrm{km}$ (50 miles) of the facility or release point. It is expressed in units of person-rem or personsieverts.

\subsection{Requirements}

Table $8-1$, beginning on page 50 , itemizes the dose calculation requirements and associated regulatory and/or guidance "drivers" with which SRS will comply. Where appropriate, specific interpretation and/or clarifying discussion of a requirement is provided. Unless otherwise noted, all requirements listed are applicable to radiological and nonradiological environmental monitoring programs.

Implementation of these requirements will be documented in the SRS EM Program. Any requirements not fully implemented will be included in the SRS EM Plan Corrective Action Plan, WSRCESH-EMS-94-0129. 


\begin{tabular}{|c|c|c|}
\hline Criteria Number and Requirement & Drivers & Discussion and/or Interpretation \\
\hline $\begin{array}{l}\text { 8.3.1 Except where mandated otherwise (e.g., compliance } \\
\text { with } 40 \text { CFR Part } 61 \text { ), the assessment models selected for all } \\
\text { environmental dose assessments will appropriately character- } \\
\text { ize the physical and environmental situation encountered. } \\
\text { The information used in dose assessments will be as accu- } \\
\text { rate and realistic as possible. }\end{array}$ & $\begin{array}{l}10 \text { CFR } 834.401 t-1 \\
10 \text { CFR } 834.401 \\
h-3 \\
\text { DOE/EH-0173T } \\
\text { (8.a) }\end{array}$ & None \\
\hline $\begin{array}{l}\text { 8.3.2 Complete documentation of models, input } \\
\text { data, and computer programs will be provided in a manner } \\
\text { that supports the annual SRS Environmental Report and will } \\
\text { be documented in the SRS Environmental Monitoring Pro- } \\
\text { gram. } \\
\text { Ref. WSRC-3Q1-2, Volume1, Section } 1108 \text {. }\end{array}$ & $\begin{array}{l}\text { DOE/EH-0173T } \\
\text { (8.b) }\end{array}$ & None \\
\hline $\begin{array}{l}\text { 8.3.3 Default values used in model applications will be doc- } \\
\text { umented and evaluated to determine appropriateness to the } \\
\text { specific modeling situation. }\end{array}$ & $\begin{array}{l}\text { DOE/EH-0173T } \\
(8 . c)\end{array}$ & None \\
\hline $\begin{array}{l}\text { 8.3.4 When performing human food chain assessments, a } \\
\text { complete set of human exposure pathways will be consid- } \\
\text { ered, consistent with current methods. }\end{array}$ & $\begin{array}{l}\text { DOE/EH-0173T } \\
(8 . d)\end{array}$ & None \\
\hline $\begin{array}{l}\text { 8.3.5 Surface and groundwater modeling will be conducted } \\
\text { as necessary to conform with the applicable requirements of } \\
\text { the state government and the EPA regional office. }\end{array}$ & $\begin{array}{l}\text { DOE/EH-0173T } \\
\text { (8.e) }\end{array}$ & $\begin{array}{l}\text { Groundwater modeling for off-site dose deter- } \\
\text { minations is not performed at SRS because con- } \\
\text { taminated groundwater has not yet migrated be- } \\
\text { yond the site boundaries. Surface water modeling } \\
\text { incorporates dispersion models described in NRC } \\
\text { Regulatory Guide 1.113. For SRS, the nontidal } \\
\text { river, complete-mixing option is used. }\end{array}$ \\
\hline
\end{tabular}




\begin{tabular}{|l|l|l|}
\hline \multicolumn{1}{|c|}{ Criteria Number and Requirement } & \multicolumn{1}{|c|}{ Drivers } & \multicolumn{1}{|c|}{ Discussion and/or Interpretation } \\
\hline $\begin{array}{l}\text { 8.3.6 The general quality assurance program provisions of } \\
\text { chapter 10 ("Quality Assurance”) of this document will be fol- } \\
\text { lowed as they apply to performing calculations that assess } \\
\text { dose impacts. }\end{array}$ & $\begin{array}{l}\text { DOE/EH-0173T } \\
(8 . \mathrm{f})\end{array}$ & None \\
\hline
\end{tabular}




\section{Records and Reports}

\subsection{General Information and Purpose}

The purpose of this chapter of the Savannah River Site Environmental Monitoring Plan (SRS EM Plan) is to define the environmental records and reports criteria, regulations, and guideline requirements with which SRS will comply.

The following regulations contain the reporting requirements applicable to SRS's environmental monitoring programs:

- 10 CFR 834 [DOE, 1993]

- U.S. Department of Energy (DOE)/EH-173T [DOE, 1991]

- DOE Order 5400.1 [DOE, 1988]

- DOE Order 5400.5 [DOE, 1990]

- DOE Order 1324.2A [DOE, 1988a]

- Clean Air Act

- Clean Water Act

- Superfund Amendments and Reauthorization Act (SARA) Title 3

- Resource Conservation and Recovery Act (RCRA)

- Comprehensive Environmental Response, Compensation, and Liability Act (CERCLA)

- Office of Management and Budget (OMB) Circular A-106

Thorough reporting and recordkeeping will be performed at SRS as essential elements of complying with state and federal regulations.

The environmental reports and notifications specified in DOE Orders 5400.1 and 5400.5 and 10 CFR 834 will be submitted to DOE within the required time periods. $\{5400.1-I, 5400.5-\mathrm{II}(7)$, and 10 CFR 834.7\}

Complete, accurate, and auditable environmental monitoring program records will be maintained. \{5400.1-IV(2.d), 5400.5-II(8.a and 8.b), and 10 CFR 834.8\}. The SRS records inventory and disposal system (RIDS) will govern environmental monitoring records management.

\subsection{Definitions}

- Record - Per DOE Order 1324.2A: Books, papers, maps, photographs, machine-readable materials, or other documentary materials, regardless of physical form or characteristics made or received by an agency of the U.S. Government under federal law or in connection with the transaction of public business and preserved or appropriate for preservation by that agency or its legitimate successor as evidence of the organization, functions, policies, decisions, procedures, operations, or other activities of the U.S. Government or because of the informational value of the data in them. This definition applies to all SRS records, regardless of quality or nonquality status or of storage media and including those created, received, and maintained by subcontractors pursuant to their contracts. 
- Report - A report is a required periodic documentation of data and/or information, concerning SRS activities, that is provided to a responsible regulatory authority.

\subsection{Requirements}

Table 9-1, page 55, itemizes the records and reporting requirements and associated regulatory and/ or guidance "drivers" with which SRS will comply. Where appropriate, specific interpretation and/ or clarifying discussion of a requirement is provided. Unless otherwise noted, all requirements listed are applicable to radiological and nonradiological environmental monitoring programs.

Implementation of these requirements will be documented in the SRS Environmental Monitoring Program (SRS EM Program), WSRC-3Q1-2, Volume 1, Section 1109. Any requirements not fully implemented will be included in the SRS EM Plan Corrective Action Plan, WSRC-ESHEMS-94-0129. 
Table 9-1 Requirements (9.3)

\begin{tabular}{|c|c|c|}
\hline Criteria Number and Requirement & Drivers & Discussion and/or Interpretation \\
\hline $\begin{array}{l}\text { 9.3.1 DOE-SR officials and SRS Management and Operating } \\
\text { contractors will identify and comply with all relevant reporting re- } \\
\text { quirements and will document it in the SRS Environmental Mon- } \\
\text { itoring Program (SRS EM Program). } \\
\text { Ref. WSRC-3Q1-2, Volume1, section } 1109 \text {. }\end{array}$ & $\begin{array}{l}10 \text { CFR } 834.401 \text { b.3 } \\
\text { DOE/EH-173T (9.a) } \\
\text { DOE Order } 5400.1 \\
\text { DOE Order 1324.2A } \\
\text { Clean Air Act } \\
\text { Clean Water Act } \\
\text { SARA Title } 3 \\
\text { RCRA } \\
\text { CERCLA } \\
\text { OMB Circular A-106 }\end{array}$ & $\begin{array}{l}\text { Records pursuant to RCRA, including mixed waste, } \\
\text { will be prepared according to the requirements of } 40 \\
\text { CFR } 264.73 \text { or } 40 \text { CFR } 265.73 \text {. }\end{array}$ \\
\hline $\begin{array}{l}\text { 9.3.2 Timely notification of occurrences and information } \\
\text { involving DOE-SR and the SRS contractors will be made to the } \\
\text { appropriate DOE officials and to other responsible authorities. }\end{array}$ & $\begin{array}{l}\text { DOE/EH-173T (9.b) } \\
\text { SIRIM system } \\
\text { DOE Order } 5400.1 \\
\text { DOE Order } 5484.2 \\
\text { CERCLA }\end{array}$ & None \\
\hline $\begin{array}{l}\text { 9.3.3 Auditable records relating to environmental surveillance } \\
\text { and effluent monitoring will be maintained. Calculations, } \\
\text { computer programs, and other data handling will be recorded or } \\
\text { referenced. }\end{array}$ & $\begin{array}{l}\text { DOE/EH-0173T } \\
\text { (9.C) } \\
\text { DOE Order } 1324.2 \mathrm{~A}\end{array}$ & $\begin{array}{l}\text { All record retention and maintenance will be in } \\
\text { accordance with written and approved procedures. }\end{array}$ \\
\hline $\begin{array}{l}\text { 9.3.4 As they apply to records and reporting activities, the } \\
\text { general quality assurance program requirements identified in } \\
\text { chapter } 10 \text { ("Quality Assurance") of this document will be fol- } \\
\text { lowed. }\end{array}$ & $\begin{array}{l}\text { DOE/EH-0173T } \\
(9 . \mathrm{d}) \\
5400.1\end{array}$ & None \\
\hline
\end{tabular}




\section{Quality Assurance}

\subsection{General Information and Purpose}

The purpose of this chapter of the Savannah River Site Environmental Monitoring Plan (SRS EM Plan) is to define the environmental monitoring quality assurance (QA) criteria, regulations, and guideline requirements with which SRS will comply.

U.S. Department of Energy (DOE) Order 5700.6C, "Quality Assurance," [DOE, 1991a] establishes requirements and guidelines for departmental QA practices. An implementation plan to address the order requirements will be developed at SRS. DOE Order 5400.1 [DOE, 1988] requires that a QA plan be prepared and included as part of each site's EM Plan. $\{5400.1-I V(10 . a)\}$ In addition, 10 CFR 834 [DOE, 1993] requires that a QA program be prepared as part of the Environmental Radiological Protection Program for each DOE site. $\{10$ CFR 834.401(I) $\}$ To ensure compliance with these regulations and to provide overall quality requirements for site programs, a QA management plan will be developed and implemented. The requirements of this management plan will be implemented in the site QA manual.

An environmental monitoring QA plan will be developed to apply the requirements of the QA manual to the site's environmental monitoring and surveillance program.

The environmental monitoring QA plan will incorporate the following QA requirements of the national consensus standard, ANSI/ASME NQA-1, "Quality Assurance Program Requirements for Nuclear Facilities"[ANSI/ASME, 1976]:

- Organization

- QA Program

- Design Control

- Procurement Document Control

- Instructions, Procedures, and Drawings

- Document Control

- Control of Purchased Items and Services

- Identification and Control of Items

- Control of Processes

- Inspection
- Test Control

- Control of Measuring and Test Equipment

- Handling, Storage, and Shipping

- Inspection, Test, and Operating Status

- Control of Nonconforming Items

- Corrective Action

- QA Records

- Audits

- Software QA

The environmental monitoring QA plan also will incorporate the following QA program requirements of 10 CFR 834 and DOE Order 5400.1:

- Organizational Responsibility

- Program Design

- Field Quality Design

- Recordkeeping
- Procedures

- Laboratory QC

- Human Factors

- Chain-of-Custody Procedures 
- Performance Reporting

- Independent Data Verification

- Audits

\{10 CFR 834.401(l.1 through l.11) and 5400.1-IV(10.a.1 through 10.a.11)\}

Subcontracted laboratories providing analytical services will be required to have a documented QA $\mathrm{QC}$ program. These laboratories also will be subject to the same in-house $\mathrm{QA} / \mathrm{QC}$ requirements defined in the environmental monitoring QA plan.

The appropriate laboratory will identify and comply with any applicable federal, state, or local laboratory certification requirements. $\{5400.1-I V(10 . c)\}$

All laboratories that conduct analytical work in support of radiological environmental monitoring programs will participate in the DOE interlaboratory QA program, coordinated by the DOE Environmental Measurements Laboratory. $\{\mathbf{5 4 0 0 . 1 - I V ( 1 0 . c ) \}}$

\subsection{Definitions}

- Audit - An audit is a planned and documented activity performed according to procedures to determine, by examination and evaluation of objective evidence, the adequacy of and extent to which applicable elements of the program have been developed, documented, and effectively implemented according to specified requirements. Audits can be either internal examinations of programs or activities under an organization's control and within its organizational structure or external examinations of programs or activities of another organization.

- Nonconforming Activity - A nonconforming activity is any activity not conducted in compliance with approved procedures or instructions, or that is performed in a manner that may cause its quality to be indeterminate or nonconforming.

- Nonconforming Item - A nonconforming item is any object having physical characteristics (materials of construction, dimensions, functions, etc.) that do not conform to specified requirements (procedures, purchase orders, drawings, etc.).

- Quality Assurance-QA refers to those planned and systematic actions necessary to provide adequate confidence that a facility, structure, system, or component will perform satisfactorily and safely in service. QA includes QC.

- Quality Control - QC refers to those actions necessary to control and verify the features and characteristics of a material, process, product, service, or activity to specified requirements. The aim of QC is to provide quality that is satisfactory, adequate, dependable, and economic.

\subsection{Requirements}

Table 10-1, beginning on page 59, itemizes the QA requirements and associated regulatory and/or guidance "drivers" with which SRS will comply. Where appropriate, specific interpretation and/or clarifying discussion of a requirement is provided. Unless otherwise noted, all requirements listed are applicable to radiological and nonradiological environmental monitoring programs.

Implementation of these requirements will be documented in the SRS Environmental Monitoring Program (SRS EM Program), WSRC-3Q1-2, Volume 1, Section 1110. Any requirements not fully implemented will be included in the SRS EM Plan Corrective Action Plan, WSRC-ESHEMS-94-0129. 
Table 10-1 Requirements (10.3)

\begin{tabular}{|c|c|c|}
\hline Criteria Number and Requirement & Drivers & Discussion and/or Interpretation \\
\hline $\begin{array}{l}\text { 10.3.3 Audits will be performed independently-according to } \\
\text { written procedures or checklists-by personnel who do not } \\
\text { have direct responsibility for performing the activities being } \\
\text { audited; i.e., supervisors cannot audit their own facilities. }\end{array}$ & $\begin{array}{l}\text { DOE/EH-0173T } \\
(10 . \mathrm{C}) \\
5400.1 \\
5700.6 \mathrm{C}\end{array}$ & None \\
\hline $\begin{array}{l}\text { 10.3.4 Audit results will be documented, reported to, and re- } \\
\text { viewed by responsible management. Followup action will be } \\
\text { taken where indicated. }\end{array}$ & $\begin{array}{l}\text { DOE/EH-0173T } \\
(10 . d) \\
5400.1 \\
5700.6 \mathrm{C}\end{array}$ & None \\
\hline
\end{tabular}




\begin{tabular}{|l|l|l|}
\hline \multicolumn{1}{|c|}{ Criteria Number and Requirement } & \multicolumn{1}{|c|}{ Drivers } & \multicolumn{1}{|c|}{ Discussion and/or Interpretation } \\
\hline $\begin{array}{l}\text { 10.3.5 The elements of a QA program will be derived from } \\
\text { the 18 criteria in ANSI/ASME NQA-1 and from those stipu- } \\
\text { lated in 10 CFR Part 50. }\end{array}$ & $\begin{array}{l}10 \text { CFR 834.401 (I) } \\
\text { DOE/EH-0173T } \\
(10 . e) \\
5400.1 \\
\text { ANSI/ASME NQA-1 } \\
10 \text { CFR 50 }\end{array}$ & $\begin{array}{l}\text { 10 CFR 834 lists 11 criteria that must be included } \\
\text { in each DOE site's QA Program, which will be } \\
\text { part of the site's Environmental Radiological } \\
\text { Protection Program. }\end{array}$ \\
\hline $\begin{array}{l}\text { 10.3.6 Radiation measuring equipment, including portable } \\
\text { instruments, environmental dosimeters, in situ monitoring } \\
\text { equipment, and laboratory instruments, will be calibrated with } \\
\text { standards traceable to NIST calibration standards. }\end{array}$ & $\begin{array}{l}\text { DOE/EH-0173T } \\
\text { (10.f) } \\
5400.1\end{array}$ & $\begin{array}{l}\text { This requirement is only applicable to radiological } \\
\text { programs. }\end{array}$ \\
\hline $\begin{array}{l}\text { 10.3.7 Other federal regulations that require QA programs } \\
\text { will be addressed in the SRS EM Program. }\end{array}$ & $\begin{array}{l}\text { Task team } \\
\text { recommendation }\end{array}$ & $\begin{array}{l}\text { This requirement will be performed in a matrix- } \\
\text { type format by reference to other documents. }\end{array}$ \\
\hline $\begin{array}{l}\text { 10.3.8 Non-EMS-generated Data. } \\
\text { Q and data analysis techniques will be consistent with EMS } \\
\text { data analysis and documented in the SRS EM Program. }\end{array}$ & $\begin{array}{l}\text { Task team } \\
\text { recommendation }\end{array}$ & None \\
\hline
\end{tabular}




\section{References}

ANS, 1984 American National Standard for Determining Meteorological Information at $\mathrm{Nu}$ clear Power Sites, ANSI/ANS-2.5, American Nuclear Society, La Grange Park, Ill. (1984).

ANSI, 1969 Guide to Sampling Airborne Radioactive Materials in Nuclear Facilities, ANSI-13.1, American National Standards Institute, Washington, D.C. (1969).

ANSI/ASME, 1976 Quality Assurance Program Requirements for Nuclear Facilities, ANSI/ ASME NQA-1, American National Standards Institute/American Society of Mechanical Engineers, Washington. D.C. (1976).

APHA, 1985 Standard Methods for the Examination of Water and Wastewater, 16th Edition, American Public Health Association, Washington, D.C. (1985).

DOE, 1981 A Guide for: Environmental Radiological Surveillance at U.S. Department of Energy Installations, DOE/EP-0023, U.S. Department of Energy, Washington, D.C. (1981).

DOE, 1988 General Environmental Protection Program, DOE Order 5400.1, U.S. Department of Energy. (November 1988).

DOE, 1988a Records Disposition, DOE Order 1324.2A, U.S. Department of Energy. (September 1988).

DOE, 1990 Radiation Protection of the Public and Environment, DOE Order 5400.5, U.S. Department of Energy (February 1990).

DOE, 1991 Environmental Regulatory Guide for Radiological Effluent Monitoring and Environmental Surveillance, DOE/EH-0173T, U.S. Department of Energy, Washington, D.C. (1991).

DOE, 1991a Quality Assurance, DOE Order 5700.6C, U.S. Department of Energy, Washington, D.C. (1991).

DOE, 1993 Radiation Protection of the Public and the Environment: Proposed Rule, 10 CFR 834, U.S. Department of Energy, Washington, D.C. (1993).

EPA, 1973a "EPA Regulations on Standards of Performance for New Stationary Sources - Appendices," U.S. Code of Federal Regulations, Title 40, Part 60, U.S. Environmental Protection Agency (1973).

EPA, 1973b "EPA Regulations on Test Procedures for the Analysis of Pollutants," U.S. Code of Federal Regulations, Title 40, Part 136, U.S. Environmental Protection Agency (1973).

EPA, 1975 "National Primary Drinking Water Regulations," U.S. Code of Federal Regulations, Title 40, Part 141, U.S. Environmental Protection Agency (1975).

EPA, 1977 National Interim Primary Drinking Water Regulations," EPA-570/9-76-003, U.S. Environmental Protection Agency (1977). 
EPA, 1979 Methods for Chemical Analysis of Water and Wastes, EPA-600/4-79-020, U.S. Environmental Protection Agency, Washington, D.C. (1979).

EPA, 1980a "Regulations for Owners and Operators of Permitted Hazardous Waste Facilities," U.S. Code of Federal Regulations, Title 40, Part 264, U.S. Environmental Protection Agency (1980).

EPA, 1980b "Interim Standards for Owners and Operators of Permitted Hazardous Waste Facilities," U.S. Code of Federal Regulations, Title 40, Part 265, U.S. Environmental Protection Agency (1980).

EPA, 1980c Procedures for Measurement of Radioactivity in Drinking Water, EPA-600/4-80-032, U.S. Environmental Protection Agency, Washington, D.C. (1980).

EPA, 1980d Upgrading Environmental Radiation Data, EPA-520/1-80-012, U.S. Environmental Protection Agency (1980).

EPA, 1982 Methods for Organic Chemical Analysis of Municipal and Industrial Wastewater, EPA-600/4-82-057, U.S. Environmental Protection Agency, Washington, D.C. (1982).

EPA, 1987a Ambient Monitoring Guidelines for Prevention of Significant Deterioration(PSD), EPA-450/4-87-007, U.S. Environmental Protection Agency, Research Triangle Park, N.C. (1987).

EPA, 1987b On-site Meteorological Program Guidance for Regulatory Modeling Applications, EPA-450/4-87-013, U.S. Environmental Protection Agency, Research Triangle Park, N.C. (1987).

EPA, 1989 "National Emission Standards for Hazardous Air Pollutants; Radionuclides," Code of Federal Regulations, Title 40, Part 61, U.S. Environmental Protection Agency (December 1989).

EPA, 1990 Quality Assurance Handbook for Air Pollution Measurement Systems: Volume $I V$ - Meteorological Measurements, EPA-600/4-90-003, U.S. Environmental Protection Agency (1990).

HASL-300, "U.S. Department of Energy Environmental Measurements Laboratory Procedures Manual" (revised annually)

NCRP, 1978 A Handbook of Radioactivity Measurements Procedures, NCRP Report 58, National Council on Radiation Protection (1978).

SCDHEC, 1976 South Carolina Department of Health and Environmental Control (SCDHEC) R.61-62, "Air Pollution Control Regulations and Standards," South Carolina Department of Health and Environmental Control, Columbia, S.C. (1976).

SCDHEC, 1992 Air Quality Modeling Guidelines, South Carolina Department of Health and Environmental Control, Columbia, S.C. (1992). 